\title{
O definicji 5 z Księgi V Elementów Euklidesa
}

\section{On Euclid's Elements Book V, definition 5}

\author{
Piotr Błaszczyk
}

Kraków

\begin{abstract}
It is well known fact that there are two definitions of proportion in Euclid's Elements: Book V, def. 5 and Book VII, def. 20. In the present paper we show that three different interpretations of definition V.5 can be given as modern notation is used: two of them arise from different readings of the definition itself, the third is a negation of disproportion ( $\mathrm{V}$, def. 7).

We define a structure of magnitudes as a relational structure $\mathfrak{W}=(W,+,<)$, the operation assumed + associative and commutative, the order $<$ assumed linear, and the relationship between + and $<$ is given by the axiom of Eudoxos ( $\mathrm{V}$, def. 4 ). We define a substructure of the ordered field of non-standard real numbers that forms the structure of magnitudes where differences between three versions of definition V.5 are shown. We use that structure to show that the axiom of Eudoxos and that of Archimedes (On the Sphere and Cylinder, axiom 5) are not equivalent. We also define two structures of magnitudes $\mathfrak{W}_{1}=\left(W,+_{1},<_{1}\right)$ and $\mathfrak{W}_{2}=\left(W,+_{2},<_{2}\right)$ and show that there are two such magnitudes $A, B \in W$, that it is not the case that $A: B:: A: B$. We finally show that there are four such magnitudes $A, B, C, D \in W$, that $A: B:: C: D$ and it is not the case that $A: C:: B: D$
\end{abstract}

Piąta księga Elementów Euklidesa zawiera wykład teorii proporcji wielkości geometrycznych (ciagłych). Przyjmuje się, że autorem tej teorii jest Eudoxos z Knidos i dlatego jest ona nazywana teorią proporcji Eudoxosa. ${ }^{1} \mathrm{~W}$ Elementach teoria proporcji (definicje i twierdzenia z Księgi V) jest stosowana w teorii figur podobnych (Księga VI), w klasyfikacji wielkości współmiernych i niewspółmiernych (Księga X), w badaniu pól oraz objętości (Księga XII).

We współczesnej geometrii teoria figur podobnych oparta jest na teorii liczb rzeczywistych w tym sensie, że jest rozwijana po wprowadzeniu miary odcinków. ${ }^{2}$ Badanie pól powierzchni oraz objętości jest obecnie działem rachunku różniczkowego i całkowego i także jest oparte na teorii liczb rzeczywistych. Stąd zapewne pochodzi przekonanie, że między teorią proporcji a teorią liczb rzeczywistych zachodzi jakiś bliski związek. Przejawem takiego myślenia są słowa Bourbakiego zawarte w Nocie historycznej poświęconej liczbom rzeczywistym:

„to Grekom zawdzięczamy pierwszą, ścisłą i spójną teorię stosunków wielkości, czyli w istocie, liczb rzeczywistych". ${ }^{3}$

\footnotetext{
${ }^{1}$ Zob. Ąnonimowy autor scholium do Księgi V (Euclid, ed. Heiberg, Vol. V, s. 280), prawdopodobnie Proklos, pisze, że 'niektórzy twierdzą', iż księga ta, zawierając ogólną teorię proporcji, która stosuje się zarówno do geometrii, arytmetyki, muzyki, jak i wszystkich nauk matematycznych, 'została odkryta przez Eudoxosa, nauczyciela Platona'"[Heath 1956], t. II, s. 113.

${ }^{2}$ Zob. [Borsuk, Szmielew 1972]. Jeszcze inaczej jest to przedstawione w [Hilbert 1930].

${ }^{3}$ [Bourbaki 1966], s. 406. Zob. także: „Równoległość greckiego pojęcia stosunku i współczesnego pojęcia liczby rzeczywistej tłumaczy, dlaczego matematyka grecka posługuje się stosunkami we wszystkich zagadnieniach, w których my sięgamy do wyobrażeń miarowych i do liczb rzeczywistych"[Kulczycki 1973], s. 196.
} 
Sama definicja proporcji („,równości stosunków") jest z kolei porównywana z konstrukcją liczb rzeczywistych przedstawiona przez Richarda Dedekinda w rozprawie Stetigkeit und irrationale Zahlen. ${ }^{4}$ I tak na przykład wybitny znawca matematyki greckiej Thomas Heath pisze:

„Jest oczywiste, że istnieje ścisła odpowiedniość, niemal zgodność, pomiędzy Euklidesa definicja równości stosunków i współczesną teorią liczb niewymiernych pochodząca od Dedekinda". 5

Niniejszy artykuł poświęcony jest dwóm szczegółowym kwestiom związanym z teorią proporcji Eudoxosa: analizie samej definicji proporcji oraz analizie pojęcia wielkości. Pokazujemy, że definicję proporcji podaną w Elementach można interpretować na trzy sposoby i wskazujemy na pewne zależności między tymi wersjami. W związku z pojęciem wielkości występującym w Księdze V definiujemy strukturę wielkości i wskazujemy na konsekwencje różnych założeń nakładanych na tę strukturę.

1. Zacznijmy od podstawowych faktów. Powstanie Elementów określa się tak samo jak okres życia Euklidesa: około roku 300. p.n.e. ${ }^{6}$ Oryginału nie odnaleziono. Tekst grecki został ustalony przez Johana L. Heiberga i wydany w latach 1883-1888. Podstawę tej edycji stanowiły manuskrypty datowane na X wiek n.e.: przede wszystkim krytyczna edycja Elementów autorstwa Theona z Aleksandrii (IV wiek n.e.), zapisy wykładów tegoż Theona oraz manuskrypt zrabowany z Biblioteki Watykańskiej przez wojska napoleońskie i odkryty w Paryżu w roku1808 przez Francois Peyrarda. ${ }^{7}$ Przy ustalaniu tekstu Elementów uwzględniano przekłady i komentarze arabskie oraz łacińskie. ${ }^{8}$

Współczesne tłumaczenia Elementów opierają się na edycji Heiberga. ${ }^{9} \mathrm{~W}$ artykule opieramy się na tłumaczeniu Heath'a. ${ }^{10}$

\footnotetext{
${ }^{4}$ Zob. [Dedekind 1872].

${ }^{5}$ [Heath 1956], II, s. 124. Zob. także: ,definicja Eudoksosa [...] jest formalnie równoważna teorii liczb niewymiernych Dedekinda"[Baron 1969], s. 27; ,Między teoriami Eudoksosa i Dedekinda istnieje [...] głęboka analogia [...]"[Baszmakowa 1975], s. 107; „W księgach V i VI Euklides operuje stosunkiem dowolnych wielkości - buduje tam, w zasadzie, teorię liczby rzeczywistej i teorię miary"[Baszmakowa 1975], s. 121; „Choć Eudoksos nie uważał, jak my, stosunku dwóch wielkości niewspółmiernych za liczbę, to jednak jego definicja proporcji wyraża ideę uporządkowania, zawartą obecnie w pojęciu liczby rzeczywistej"[Boyer 1964], s. 55; „Dedekind (a przed nim autor - uważa się, że był to Eudoksos - piątej księgi [Elementów - P.B.] Euklidesa) skonstruował liczby rzeczywiste z liczb wymiernych"[Conway 2001], s. 3; ,odtwarzając niektóre kroki Eudoksosa sprzed ponad dwóch tysięcy lat, Dedekind ustanowił solidne podstawy systemu liczb rzeczywistych"[Edwards 1979], s. 14; „Proporcje to liczby rzeczywiste dodatnie [...]. Co więcej, nie tylko takie same, lecz wręcz te same, które aksjomatycznie zdefiniował Dedekind w 1872 roku"[Kordos 1994], s. 69; „W wymienionej definicji Eudoksosa tkwi już w zarodku podstawowa idea Dedekinda: definicja liczby niewymiernej jako przekroju w dziedzinie liczb wymiernych"[Kostin 1952], s. 28; „Jeżeli zatem rozpatrywać problem równości i uporządkowania, pojęcia stosunku i dodatniej liczby rzeczywistej (przekroju) pokrywałyby się, o ile tylko dowolnemu przekrojowi odpowiadałyby wielkości $\alpha$ i $\beta$, o stosunku wyznaczającym ów przekrój"[Kulczycki 1973], s. 196; „Potencjalnie, teoria proporcji nie różni się od teorii liczb rzeczywistych: każda proporcja pojawiająca się w rozważaniach geometrycznych lub fizycznych może być reprezentowana przekrojem Dedekinda"[Mioduszewski 1996], s. 69; „Piąta definicja teorii stosunków Eudoksosa jest ważna, gdyż kryje w sobie podstawowe pojęcie matematyki współczesnej - pojęcie przekroju zbioru liczb rzeczywistych"[Nikolić 1974], s. 230; „Obecna teoria liczb niewymiernych rozwinięta przez Dedekinda i Weierstrassa, postępuje niemal dosłownie za sposobem Eudoksosa"[Struik 1960], s. 31; „Dla Eudoksosa liczba rzeczywista jest dana jako stosunek dwóch odcinków"[Weyl 1949], s. 39; ,w definicji Eudoksosa tkwiło implicite pojęcie przekroju Dedekinda: dwa stosunki $P / Q$ i $X / Y$ są równe wtedy i tylko wtedy, gdy zbiory liczb wymiernych, które je oszacowują z góry (z dołu) są równe"[Więsław 1997], s. 38.

${ }^{6}$,W średniowieczu większość tłumaczy i wydawców mówiło o Euklidesie jako Euklidesie z Magary. Określenie to wynika z pomylenia naszego Euklidesa z filozofem Euklidesem z Magary, który żył około 400 p.n.e."[Heath 1956], I, s. 3.

${ }^{7}$ Peyrard przetłumaczył Elementy na język francuski (wydane w 1804), a w latach 1814-1818 opublikował jedną z cenniejszych edycji greckiego tekstu wszystkich trzynastu Ksiąg Elementów.

${ }^{8}$ Zob. [Heath 1956], I, Wstep, ss. 1-151, [Fowler 1999], rozdz. VI; zob także: [Aaboe 1968], ss. 40-42, [Kline 1972], ss. 56-58, [Kulczycki 1973], ss. 250-256.

${ }^{9}$ Zupełnie niedawno wybitny historyk matematyki greckiej Wilbur Knorr zgłosił zastrzeżenie wobec tej edycji. Zob. [Knorr 1996].

${ }^{10}$ Zob. [Heath 1956]. Cytując Elementy, zgodnie ze zwyczajem, podajemy numer księgi (w notacji rzymskiej) oraz numer twierdzenia lub definicji (w notacji arabskiej).
} 
2. W przekładach Elementów na języki nowożytne można wydzielić dwa nurty. ${ }^{11} \mathrm{~W}$ pierwszym Elementy traktowane są jako wykład i źródło wiedzy matematycznej. Te wydania pozbawione są wrażliwości filologicznej i historycznej. W zależności od uznania autora i zrozumienia tekstu zmieniane są definicje, dowody, dodawane lub pomijane twierdzenia. Dla przykładu w Elementach, które w roku 1804 wydał John Playfair definicja proporcji z Księgi V jest zupełnie inna niż definicja Euklidesa, mianowicie:

„Four magnitudes are proportional, when any multiple of the first contains the second (with or without the remainder), as often as the same multiple of the third contains the fourth". ${ }^{12}$

Na przełomie XVIII i XIX wieku, gdy Elementy zaczęto traktować jako podręcznik matematyki, kolejne wydania były podporządkowywane wymogom dydaktyki. Tu także nie przywiązywano wagi do zgodności tekstu z oryginałem. Do wyjątków należą pełne wydania. Elementy traktowano jako rzecz o geometrii, stąd najczęściej wydania obejmowały Księgi I-VI, rzadziej już Księgi I-VI oraz XI-XII. ${ }^{13}$ Z drugiej strony znane są też wydania, w których Elementy liczą Ksiąg piętnaście.

Obok tego, poczynając od XVII wieku, powstawały edycje, w których konfrontując kolejne wydania i komentarze próbowano odtworzyć „oryginalny tekst Euklidesa". ${ }^{14}$ Zwieńczeniem tego nurtu jest edycja Heiberga. Poczynając od tej edycji wyraźnie oddziela się tekst Elementów od tego, co jest uznawane za interpretację, czy komentarz. ${ }^{15}$ Znamienne, że zbiega się to w czasie z ustaleniem matematycznego standardu odczytania Elementów, a za taki uznajemy Grundlagen der Geometrie Davida Hilberta. W XX wieku ,geometria Euklidesa"to system aksjomatyczny ustalony w zasadniczym kształcie przez Hilberta w roku 1899.

3. Przez wieki Elementy były uznawane za wzór metody dedukcyjnej. Z czasem zaczęto znajdować w wykładzie Euklidesa „luki", tj. nie wyjawione w formie aksjomatów czy postulatów założenia wykorzystywane w dowodach. Typowe przykłady takich „luk"w wykładzie geometrii to aksjomat Pascha oraz aksjomat ciągłości; w teorii proporcji - założenie o istnienia czwartej proporcjonalnej. W kolejnych partiach artykułu zobaczmy, jak w różnych komentarzach wypełniane są owe „luki"w teorii proporcji dotyczące pojęcia wielkości.

4. Wielkość $(\mu \varepsilon \gamma \varepsilon \theta o \varsigma)$. Wielkość podpada pod kategorię ilości. W Kategoriach Arystoteles pisze :

„Ilość jest bądź rozdzielna, bądź ciągła. [...] Przykładem ilości rozdzielnej jest liczba i mowa, przy-

\footnotetext{
${ }^{11}$ Informacje podane w tym punkcie podajemy za: [Goldstein 2000] oraz [Heath 1956], Wstęp, część VIII Translations and Editions.

${ }^{12}$ Euclides, Elements of Geometry: Containing the First Six Books of Euclid, with a Supplement on the Quadrature of the Circle and the Geometry of Solids, To Which Are Added, Elements of Plane and Spherical Trigonometry by John Playfair, F.R.S., Edinburgh 1804, s. 296 - cytowane za [Goldstein 2000], s. 46; tytuł i dane edycji Playfair'a za [Goldstein 2000], s. 52. Definicję Euklidesa V.5 podajemy w punkcie 8.

${ }^{13}$ Takie jest właśnie jedyne polskie tłumaczenie: Euklidesa początków geometrii ksiag ośmioro, to iest sześć pierwszych, jedenasta i dwunasta z dodanemi przypisami dla pożytku młodzi akademickiej wyttumaczone przez Józefa Czecha, Wilno 1817. Część VIII Wstęu do Elementów w tłumaczeniu Heath'a traktuje o przekładach na języki nowożytne. Tłumaczenie Czecha jest tam dodane w nawiasie do grupy dziesiątej Jezyk rosyjski: „(1817. A translation into Polish by Jo. Czecha.)"[Heath 1956], I, s. 113.

${ }^{14}$ Goldstein zalicza do tego nurtu: (1) The English Euclid: Being the First Six Elements of Geometry, Translated out of Greek with Annotations and Useful Supplements by Edmunda Scarbrugh, Oxford 1705, (2) Euclid's Elements Volume II Containing the Seventh, Eight, Ninth, Thirteenth, Fourteenth and Fifteenth Books: With the Data Being the Remaining Parts of That Work Which Were Not Publish'd by the Late Dr. Keil, trans. Edmund Stone, London 1731, (3) Robert Simson, The Elements of Euclid viz. The First Six Books, Together with the Eleventh and Twelfth. The Errors by Which Theon and Others Have Long Ago Vitiated These Books, are Corrected and Some of Euclid's Demonstrations Are Restored, Philadelphia 1810. Tytuły i dane edycji podajemy za [Goldstein 2000], ss. 52-53.

${ }^{15} \mathrm{Z}$ jednej strony w wielu XX-wiecznych wydaniach pism matematycznych antycznej Grecji stosowana jest symbolika nie występująca $w$ oryginale, $\mathrm{z}$ drugiej, w zupełnie najnowszych edycjach, właśnie w trosce o zgodność z oryginałem, nie tylko że nie wprowadza się do tłumaczenia żadnych obcych elementów, ale nawet zachowuje się typografię tekstu.
} 
kładem ilości ciąłej jest linia, powierzchnia, ciało a ponadto czas i miejsce". ${ }^{16}$

W Elementach znajdujemy dwa rodzaje wielkości: liczby i wielkości geometryczne (wielkości ciagłe). ${ }^{17}$

5. Liczba $(\alpha \rho \imath \theta \mu o \varsigma)$. Liczba to liczba naturalna poczynając od 2; 1 nie jest liczbą - jest jednostką, z której powstają liczby; zero nie występuje w Elementach ${ }^{18}$ Dwie liczby mogą być równe, jedna może być większa lub mniejsza od drugiej. Liczby można dodawać, mnożyć i odejmować mniejsza od większej. Mnożenie jest definiowane przez dodawanie. Przemienność mnożenia jest dowodzona. ${ }^{19}$ Relacja mniejszości nie jest definiowana. Do tej charakterystyki dodajemy aksjomat indukcji. Nie jest on explicite sformułowany, ale jest stosowany. Otóż w dowodzie twierdzenia V.8 mamy, że wielkość $D$ jest mniejsza od wielkości $K$ i w odniesieniu do nich Euklides pisze:

„let $L$ be taken double of $D, M$ triple of it, and successive multiples increasing by one, until what is taken is a multiple of $D$ and the first that is greater than $K "{ }^{20}$

Z założenia, wielkości $D$ i $K$ są archimedesowe, stąd dla pewnej liczby naturalnej $n$ zachodzi $n D>$ $K$. Euklides przyjmuje jednak istnienie takiej liczby naturalnej, która spełnia warunek $(n+1) D>K \geq$ $n D$. Liczba taka istnieje przy założeniu, że w dowolnym niepustym zbiorze liczb naturalnych istnieje element najmniejszy, a warunek ten jest równoważny aksjomatowi indukcji. ${ }^{21}$

5.1. W Elementach ułamki nie są liczbami. ${ }^{22}$ Liczba może natomiast być „częścią"innej liczby:

„A number is a part of a number, the less of the greater, when it measures the greater, but parts when it does not measure it", 23

„The greater number is a multiple of the less when it is measured by the less," 24

„Numbers are proportional when the first is the same multiple, or the same part, or the same parts, of the second that the third is of the fourth". ${ }^{25}$

Gdy $A=n B$, to $A$ jest wielokrotnością $B$, gdy $B=m A$, to $A$ stanowi część-part $B$. Natomiast w odniesieniu do przypadku część-parts David Fowler pisze:

„Euklides nigdzie nie wyjaśnia, ani wprost w definicji, ani implicite w jakimś twierdzeniu, jak traktować przypadek, gdy pierwsza liczba jest 'parts' drugiej, dlatego nie wiemy, jak interpretować 'same parts'". ${ }^{26}$

Ivor Grattan-Guinessem podaje natomiast taką interpretację pojęcia „parts": Niech $m<n$. Gdy $k \cdot m=n$, to $m$,mierzyłiczbę $n$ i stanowi część-part ( $\mu \varepsilon \rho o \varsigma)$ liczby $n$. Gdy $k \cdot m+l=n$, to $m$ stanowi część-parts ( $\mu \varepsilon \rho \eta)$ liczby $n$. W ten sposób 3 stanowi część-part 9, natomiast 3 jest taką samą częścią-

\footnotetext{
${ }^{16}$ [Arystoteles], 6. 4b.

${ }^{17}$ Grattan-Guiness do wielkości zalicza także stosunki. Zob. [Grattan-Guiness 1996], s. 362.

${ }^{18}$ Zob. „An unit is that by virtue of which each of the things that exist is called one"[Euklides], VII, def. 2, „A prime number is that which is measured by an unit alone"[Euklides], VII, def. 11.

${ }^{19}$ Zob. „A number is said to multiply a number when that which is multiplied is added to itself as many times as there are units in the other, and thus some number is produced"[Euklides] VII, def. 15 oraz ,If two numbers by multiplying make certain numbers, the numbers so produced will be equal to one another"[Euklides], VII, tw. 16.

${ }^{20}$ [Euklides], V, tw. 8.

${ }^{21}$ Zob. też dowód twierdzenia: „Any composite number is measured by some prime number", [Euklides], VII, tw. 31.

${ }^{22}$ Zob. [Fowler 1999], [Grattan-Guiness 1996], [Kline 1972].

${ }^{23}$ [Euklides], VII, def. 3.

${ }^{24}$ [Euklides], VII, def. 5.

${ }^{25}$ [Euklides], VII, def. 20.

${ }^{26}$ [Fowler 1999], s. 16.
} 
parts 7 jak 6 jest częścią-parts $14 .^{27}$

6. Wielkości geometryczne. W poniższej tabeli powtarzamy za Grattan-Guinessem klasyfikację wielkości geometrycznych występujących w Elementach: ${ }^{28}$

\begin{tabular}{|c|c|c|}
\hline Wielkości geometryczne & Prostoliniowe & Krzywoliniowe \\
\hline \hline linia & prosta & $\begin{array}{c}\text { krzywa płaska } \\
\text { np. łuk okręgu }\end{array}$ \\
\hline obszar & $\begin{array}{c}\text { płaski prostoliniowy } \\
\text { np. prostokąt }\end{array}$ & $\begin{array}{c}\text { płaski krzywoliniowy } \\
\text { np. wycinek koła }\end{array}$ \\
\hline powierzchnia & prostoliniowa & krzywoliniowa \\
& np. czworościan & np. kula \\
\hline bryła & prostoliniowa & krzywoliniowa \\
& np. szcześcian & np. kula \\
\hline kąt & płaski & bryłowy \\
\hline
\end{tabular}

Przyjmujemy, że w różnych komórkach występują wielkości różnego rodzaju. Tak więc na podstawie tego ustalenia np. kwadrat i koło są wielkościami różnego rodzaju.

6.1. Wielkości geometryczne różnych rodzajów nie są porównywane. Wielkości geometryczne tego samego rodzaju są uporządkowane: jedna jest większa, mniejsza bądź równa drugiej. ${ }^{29}$

Wielkości geometryczne tego samego rodzaju można dodawać. Związane z pojęciem wielokrotności mnożenie wielkości przez liczbę rozumiemy jako iterację dodawania; przyjmujemy, że zapis $2 A$ oznacza $A+A$, ogólnie, zapis $n A$ oznacza

$$
\underbrace{A+\cdots+A}_{n-\text { razy }}
$$

gdzie + jest dodawaniem wielkości danego rodzaju. ${ }^{30}$

Generalnie, wielkości tego samego rodzaju nie są mnożone. Jest natomiast w Elementach jedno twierdzenie - VI, tw. 23 - o którym przyjmuje się, że występuje w nim mnożenie odcinków, a wynikiem jest prostokąt. W przypadku wielkości innych niż odcinki, mnożenie trudno jest w ogóle zinterpretować, bo cóż np. miałoby być wynikiem działania kąt $\times$ kąt $?^{31}$

Powyższe tezy są powszechnie akceptowane. Ze swej strony dodajmy do tego następującą wątpliwość. Jeżeli wynikiem dodawania ma być wielkość tego samego rodzaju co $A$, to tylko w przypadku odcinków wyznaczenie sumy jest proste. Gdy $A$ jest kwadratem, a wynik też ma być kwadratem, to wykonalność tej operacji uzasadnia twierdzenie Pitagorasa. ${ }^{32}$ Ale już wykonalność operacji $2 K$, gdzie $K$ jest danym kołem, nie jest bynajmniej oczywista.

Jeżeli wykonalność operacji $n A$ winna być uzasadniona geometrycznie, to operacja odwrotna, tj. wyznaczenie takiego $B$, że $A=n B$, może w ogóle nie być wykonalna; vide zagadnienie trysekcji kąta, czy podwojenia sześcianu. ${ }^{33}$

\footnotetext{
${ }^{27}$ Zob. [Grattan-Guiness 1996], s. 362.

${ }^{28}$ Zob. [Grattan-Guiness 1996], s. 363.

${ }^{29}$ Dana wielkość nie jest porównywana sama z sobą.

${ }^{30}$ Podstawą takiej interpretacji jest dowód twierdzenia V.15. (Gdy wielkość $A$ pochodzi ze struktury, w której zdefiniowane jest mnożenie, wówczas wyraźnie piszemy $n \cdot A$.)

${ }^{31}$ Zob. [Grattan-Guiness 1996], s. 364-365.

${ }^{32}$ Zob. „In right-angled triangles the squares on the side opposite the right angle equals the sum of the squares on the sides containing the right angle"[Euklides], I, tw. 47.

${ }^{33}$ Por. „W dziedzinie odcinków istnieje operacja odwrotna do operacji dodawania - podział: gdy dany jest odcinek $a$ i liczba naturalna $n$, to istnieje jeden i tylko jeden [...] taki odcinek $x$, że $n x=a$; jest on oznaczany jako $a / n$. Operacja podziału może być składana z dodawaniem. W ten sposób np. $5 a / n$ nazywamy $5 / 3$ razy’ $a$. Symbol ułamka $m / n$ służy tu za symbol złożenia operacji, tak że dwa ułamki są równe jeśli operacje przez nie oznaczone prowadzą do tego samego wyniku, bez względu na to, do jakiego odcinka $a$ są zastosowane. [...] Nie ma potrzeby wprowadzać specjalnych ułamków dla każdej dziedziny wielkości"[Weyl 1949], s. 30-31.
} 


\subsection{Aksjomat Archimedesa. Definicja V.4:}

„Magnitudes are said to have a ratio to one another which are capable, when multiplied, of exceeding one another"; 34

(E) $\exists n \in \mathbb{N}[n A>B]$.

Podobny warunek, jako aksjomat 5 , podaje Archimedesa w trakcie $O$ walcu $i$ kuli:

„Of unequal lines, unequal surfaces, and unequal solids, the greater exceeds the less by such a magnitude as, when added to itself, can be made to exceed any assigned magnitude among those which are comparable with [it and with] another one"; 35

$$
A<B \rightarrow \exists n \in \mathbb{N}[n(B-A)>B \wedge n(B-A)>A] .
$$

Warunek (E) jest nazywany albo aksjomatem Eudoxosa, albo aksjomatem Archimedesa, albo aksjomatem Archimedesa-Eudoxosa, albo aksjomatem Eudoxosa-Archimedesa. ${ }^{36}$ Podobnie warunek (A) jest nazywany aksjomatem Archimedesa, albo Eudoxosa-Archimedesa. ${ }^{37}$

6.4. W Elementach wielkości geometryczne tego samego rodzaju spełniają, ex definitione, warunek (E) i w związku z tym nazywane są w literaturze wielkościami archimedesowymi. Pokażemy, że warunki (A) i (E) nie są równoważne, ${ }^{38}$ mimo to będziemy respektować zastany zwyczaj językowy. Tak więc, w artykule przyjmujemy, że wielkości archimedesowe, to wielkości spełniające warunek (E). Biorąc pod uwagę powyższe ustalenia, przez strukturę wielkości rozumiemy strukturę relacyjną $\mathfrak{W}=(W,+,<)$, gdzie działanie jest wewnętrzne, łączne i przemienne, ${ }^{39}$ porządek $<$ jest liniowy, ${ }^{40}$ a warunek (E) określa związek między dodawaniem i porządkiem wielkości.

6.5. W liście Richarda Dedekinda do Rudolfa Lipschitza czytamy, że Lipschitz miał powiedzieć o zasadzie ciągłości Dedekinda:

„nie przeczę, iż Pańska definicja [zasada ciągłości - P.B.] jest uprawniona, ale uważam, że różni się ona tylko co do formy zewnętrznej, nie zaś co do istoty, od tego, co stwierdzili już starożytni. Mogę tylko powiedzieć, że uważam definicję umieszczoną w ks. V Euklidesa jako definicję 4, a brzmiącą w wersji łacińskiej: rationem habere inter se magnitudes dicuntur, quae possunt multiplicate sese munto supreme, za równie zadowalającą jak Pańska". ${ }^{41}$

Dzisiaj jest wręcz niezrozumiałe, że „za równie zadowalające"można było uznać warunek (E) i zasadę ciągłości Dedekinda. Z odpowiedzi Dedekinda przytoczymy jednak tylko ten fragment, w którym jest mowa o tym, jak w Elementach scharakteryzowane jest to „dosyć niejasne i skomplikowane"pojęcie wielkości. Otóż zdaniem Dedekinda wprost podana jest tylko własność zawarta w

\footnotetext{
${ }^{34}$ [Euklides], V, def. 4.

${ }^{35}$ [Archimedes], Księga I, s. 4.

${ }^{36}$ Zob. ,aksjomat Archimedesa"[Baszmakowa 1975], s. 106, „aksjomat Archimedesa (który był zresztą wcześniej wyczuwany przez Eudoksosa)"[Coxeter 1967], s. 219, ,aksjomat Eudoksosa"[Edwards 1979], s. 12, ,postulat Archimedesa"[Mioduszewski 1996], s. 65, ,aksjomat Archimedesa-Eudoksosa"[Klein 1972], s. 81, ,aksjomat EudoksosaArchimedesa"[Rosenfeld 1988], s. 44.

${ }^{37}$ Zob. ,,aksjomat Eudoksosa-Archimedesa"[Baszmakowa 1975], s. 132; ,,aksjomat Archimedesa albo aksjomat Eudoksosa-Archimedesa", [Batóg 2000], s. 23.

${ }^{38}$ Zob. niżej pkt. 9.4.

${ }^{39}$ Zob. dowód twierdzenia V.1.

${ }^{40}$ Przechodniość jest zakładana w dowodzie twierdzenia V.8, prawo trychotomii - w dowodach prowadzonych metodą nie wprost: V.9, V.10, V.18.

${ }^{41}$ [Dedekind 1876], s. 149-150. Najpewniej to właśnie te słowa Lipschitza ma na uwadze Baszmakowa, gdy pisze: „Między teoriami Eudoksosa i Dedekinda istnieje tak głęboka analogia, że w jednym z listów do Dedekinda R. Lipschitz zapytywał go, co właściwie zdziałał nowego w porównaniu ze starożytnymi"[Baszmakowa 1975], s. 107; zob. także [Mioduszewski 1996], s. 69.
} 
definicji V.4. Milcząco natomiast zakłada się, że wielkości są uporządkowane liniowo oraz to, że wielokrotności $n A$ są wielkościami tego samego rodzaju co $A .{ }^{42}$

6.6. Dla porównania zobaczmy jeszcze, co o wielkościach wyczytał z Elementów Nicolas Bourbaki:

„Wielkości tego samego rodzaju są scharakteryzowane przez to, że mogą być porównywane (to znaczy, przyjmuje się, że zdefiniowana jest równość, która jest relacją równoważności, oraz relacja < i $>$ ), mogą być dodawane i odejmowane (zdefiniowane jest $A+B$ oraz $A-B$, gdy $A>B$ ) oraz, że spełniaja 'aksjomat Archimedesa'". ${ }^{33}$

„Aksjomat Archimedesaóznacza tu warunek:

$$
(a>0, b>0) \rightarrow \exists n \in \mathbb{N}[n a>b] .^{44}
$$

Zważywszy, że element neutralny 0 nie ma interpretacji geometrycznej, należy przyjąć, że Aksjomat Archimedesa to warunek (E).

„Zauważmy, że dla Eudoksosa wielkości tego samego rodzaju tworzą system z jednym działaniem wewnętrznym (dodawaniem), ale system ten posiada też zewnętrzne prawo kompozycji, którego operatorami są stosunki wielkości, o których przyjmuje się, że tworzą grupę abelową. [...] To, że stosunki wielkości każdego rodzaju tworzą dziedzinę operatorów jest równoważne aksjomatowi (nie sformułowanemu explicite, ale często stosowanym w dowodach Euklidesa) o istnieniu czwartej proporcjonalnej: gdy dany jest stosunek $A / A^{\prime}$ i dane jest $B$, to istnieje takie $B^{\prime}$ tego samego rodzaju, co $B$, że zachodzi $B / B^{\prime}=A / A^{\prime \prime} .{ }^{45}$

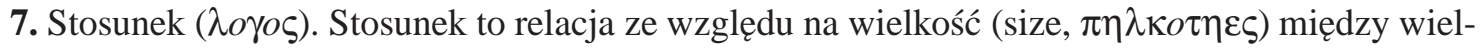
kościami (magnitudes, $\mu \varepsilon \gamma \varepsilon \theta o \varsigma$ ) tego samego rodzaju;

„A ratio is a sort of relation in respect of size between two magnitudes of the same kind". ${ }^{46}$

7.1. Powszechnie przyjmuje się, że Euklides nie podał definicji stosunku. Z drugiej strony, w interpretacjach, w których teorię proporcji przyrównuje się do teorii liczb rzeczywistych, to właśnie stosunkowi przyporządkowuje się liczbę rzeczywistą, a zdarza się nawet, że teoria proporcji jest nazywana teorią stosunków. Historyczne tło kontrowersji związanej z tym, czy w Księdze V znajdujemy teorię stosunków, czy teorię proporcji jest takie: przed sformułowaniem teorii Eudoksosa w matematyce greckiej funkcjonowały dwie inne teorie proporcji, w obydwu był zdefiniowany stosunek, a proporcja polegała na porównaniu stosunków. ${ }^{47}$

8. Proporcja ( $\alpha \vee \alpha \lambda o \gamma(\alpha)$. Definicja V.5 to definicja proporcji:

„Magnitudes are said to be in the same ratio, the first to the second and the third to the fourth, when, if any equimultiples whatever be taken of the first and third, and any equimultiples whatever of the second and fourth, the former equimultiples alike exceed, are alike equal to, or alike fall short of, the latter equimultiples respectively taken in corresponding order". ${ }^{48}$

\footnotetext{
${ }^{42}$ Zob. [Dedekind 1876], s. 151.

${ }^{43}$ [Bourbaki 1966], s. 408. Zob. także: „Zbudowana w ten sposób uniwersalna dziedzina operatorów była dla matematyków greckich, tym, czym dla nas jest zbiór liczb rzeczywistych; jest ponadto oczywiste, że wraz z dodawaniem wielkości i mnożeniem stosunków wielkości posiadali oni równoważnik tego, czym ciało liczb rzeczywistych jest dla nas"[Bourbaki 1966], s. 409.

${ }^{44}$ Zob. [Bourbaki 1966(a)], s. 334.

${ }^{45}$ [Bourbaki 1966], s. 408-409.

${ }^{46}$ [Euklides], V, def. 3.

${ }^{47}$ Zob. [Berggren 1984], [Fowler 1999].

${ }^{48}$ [Euklides], V, def. 5. W thumaczeniu Fabio Acerbi: „Magnitudes are said to be in the same ratio, first to second and
} 
Definicja V.6 ustala nazwę:

„Let magnitudes which have the same ratio be called proportional". 49

W Elementach równość ( $1 \sigma o \varsigma$ ) odpowiada i przystawaniu i równości pól. ${ }^{50} \mathrm{~W}$ definicji proporcji jest powiedziane, że stosunki występujące w proporcji są ,te same", a nie równe, dlatego zgodnie ze zwyczajem, stosunek wielkości $A$ i $B$ zapisujemy jako $A: B$, a proporcję jako $A: B:: C: D{ }^{51}$

8.1. Spróbujmy narzucić na definicję proporcji siatkę współczesnej notacji logicznej. Wśród znawców matematyki greckiej, a i wśród komentatorów bazujących na tłumaczeniach, funkcjonują trzy wersje:

$$
\begin{aligned}
& A: B:: C: D \leftrightarrow_{d f} \forall m, n\left[\left(n A>_{1} m B, n C>_{2} m D\right) \vee\right. \\
& \left.\vee(n A=m B, n C=m D) \vee\left(n A<_{1} m B, n C<_{2} m D\right)\right],
\end{aligned}
$$

$$
\begin{gathered}
A: B:: C: D \leftrightarrow_{d f} \forall m, n\left[\left(n A>_{1} m B \rightarrow n C>_{2} m D\right) \wedge\right. \\
\left.\wedge(n A=m B \rightarrow n C=m D) \wedge\left(n A<_{1} m B \rightarrow n C<_{2} m D\right)\right],
\end{gathered}
$$

$$
\begin{gathered}
A: B:: C: D \leftrightarrow d f \forall m, n\left[\left(n A>_{1} m B \leftrightarrow n C>_{2} m D\right) \vee\right. \\
\left.\vee(n A=m B \leftrightarrow n C=m D) \vee\left(n A<_{1} m B \leftrightarrow n C<_{2} m D\right)\right] .{ }^{52}
\end{gathered}
$$

gdzie wielkości $A, B$ oraz $C, D$ są parami tego samego rodzaju, co zapisujemy jako $A, B \in \mathfrak{W}_{1}=$ $\left(W_{1},+,<_{1}\right)$ oraz $C, D \in \mathfrak{W}_{2}=\left(W_{2},+,<_{2}\right),{ }^{53}$ przyjmujemy też, że $m, n \geq 1$.

Fabio Acerbi analizując użycia spójnika $\alpha \mu \alpha$ w Elementach, u Arystotelesa i Archimedesa przyjmuje definicję (3). Dalej tak pisze:

„W takiej wersji (nie)równości występujące w każdej parze muszą być jednocześnie spełnione lub jednocześnie niespełnione, podczas gdy wersja 'i' wymaga tylko tyle, aby były one jednocześnie spełnione". 54

third to fourth, when the equimultiples of the first and third at the same time exceed or at the same time are equal to or at the same time fall short of the equimultiples of second and fourth, compared to one another, whatever [is] each multiple of each [magnitude]"[Acerbi 2003], s. 194.

${ }^{49}$ [Euklides], V, def. 6.

${ }^{50}$ Dla tego drugiego rozumienia równości kluczowe jest twierdzenie 35 z Księgi I. Nie jest jednak tak, że równość odcinków to równość długości w dzisiejszym rozumieniu, a równość figur to równość pół dzisiejszym rozumieniu. Zob. [Grattan-Guiness 1996], [Fowler 1999], [Klein 1972], [Kulczycki 1973]. Por. „W aksjomatach Euklidesa równość oznacza i identyczność i równość pod względem wielkości; więc np. równość dwóch odcinków to równość ich długości [...], równość dwóch kół [...] to równość ich pól"[Batóg 2000], s. 17.

${ }^{51}$ Grattan-Guiness podaje, że zwyczaj ten został zapoczątkowany w XVII wieku przez Anglików Vicenta Wing'a (stosunek) i Williama Ougethered (proporcja); zob. [Grattan-Guiness 1996], s. 365-366. Zdarza się, że w komentarzach proporcja jest nazywana równością stosunków. Czasami stosunek nazywany jest proporcją i wówczas o proporcji Eudoksosa mówi się, że ,proporcje $a: b$ i $c: d$ są równe"[Mioduszewski 1996], s. 64.

${ }^{52}$ F. Acerbi podaje, że w najnowszej francuskiej edycji Elementów (Euclide 1990-2001, Les Éléments, tłumaczenie i komentarz B. Vitrac) przyjęto wersję (1), zaś I. Mueller w książce Philosophy of Mathematics and Deductive Structure in Euclides Elements (MIT, Cambrigde 1981), uwzględniając stosowanie definicji, przyjmuje wersję (2); zob. [Acerbi 2003], s. 194. W komentarzach, acz rzadko zapis definicji jest jednoznaczny, podaje się: wersję (1) - [Baszmakowa 1975], s. 106, [Edwards 1979], s. 13, [Stein 1990], s. 168, wersję (2) - [Bourbaki 1966], s. 409, [Klein 1972], s. 69, [Mioduszewski 1996], s. 64, [Weyl 1949], s. 39, wersję (3), a być może (2') - [Baron 1969] s. 27, [Hale 2000], s. 107, [Nikolić 1974], s. 230, [Więsław 1997], s. 38. O ile jednak Acerbi, Mueller, Vitrac uzasadniają swoje wybory, to we wskazanych komentarzach w ogóle nie zauważa się, że dokonywany jest jakiś wybór.

${ }^{53}$ Pomijamy indeksy przy symbolu dodawania.

${ }^{54}$ Zob. [Acerbi 2003], ss. 193-197. 
8.2. Przyjmujemy, że dla każdej pary $(m, n)$ wielkości $m A, n B$ oraz $m C, n D$ spełniają prawo trychotomii. Przy tym założeniu warunki (1) i (2) są równoważne. ${ }^{55}$ Dla porządku podamy jeszcze jedną wersję definicji V.5, częściowo uwzględniającą filologiczne analizy Acerbi, mianowicie:

$$
\begin{gathered}
A: B:: C: D \leftrightarrow{ }_{d f} \forall m, n\left[\left(n A>_{1} m B \rightarrow n C>_{2} m D\right) \wedge\right. \\
\left.\wedge(n A=m B \rightarrow n C=m D) \wedge\left(n A<_{1} m B \rightarrow n C<_{2} m D\right)\right] .
\end{gathered}
$$

Wersja ta też jest równoważna wersji (1). Warunek (3) jest natomiast tautologią: dla dowolnej pary $(m, n)$, jeżeli żadna z równoważności występujących pod kwantyfikatorem nie jest postaci $1 \leftrightarrow 1$, to któraś musi być postaci $0 \leftrightarrow 0$.

Jeżeli jest tak, jak twierdzi Acerbi, że w tekście definicji V.5 odpowiednie spójniki zdaniowe to istotnie równoważność i alternatywa, wówczas w definicji (3) można zmienić pozycję kwantyfikatora i otrzymamy:

$$
\begin{gathered}
A: B:: C: D \leftrightarrow d f \forall m, n\left[\left(n A>_{1} m B \leftrightarrow n C>_{2} m D\right)\right] \vee \\
\vee \forall m, n[(n A=m B \leftrightarrow n C=m D)] \vee \forall m, n\left[\left(n A<_{1} m B \leftrightarrow n C<_{2} m D\right)\right] .
\end{gathered}
$$

Acerbi nie rozważa takiego wariantu, a jest on zgodny z jego analizami o tyle, że „(nie)równości występujące w każdej parze muszą być jednocześnie spełnione lub jednocześnie niespełnione".

\subsection{Nierówność stosunków. Definicja:}

„When, of the equimultiples, the multiple of the first magnitude exceeds the multiple of the second, but the multiple of the third does not exceed the multiple of the fourth, then the first is said to have a greater ratio to the second than the third has to the fourth". ${ }^{56}$

Tu nie ma wątpliwości: .

$$
A: B \succ C: D \leftrightarrow_{d f} \exists m, n\left[n A>{ }_{1} m B, n C \leq_{2} m D\right],
$$

gdzie $A, B \in \mathfrak{W}_{1}$ oraz $C, D \in \mathfrak{W}_{2}$.

Gdybyśmy chcieli dotrzeć do definicji proporcji wychodząc od definicji nierówności stosunków, to otrzymamy jeszcze jedną, czwartą wersją:

$$
A: B:: C: D \leftrightarrow_{d f} \neg(A: B \succ C: D) \wedge \neg(C: D \succ A: B),
$$

co daje

(4)

$$
\begin{gathered}
A: B:: C: D \leftrightarrow d f \\
\forall m, n\left[\left(m A \leq_{1} n B, m C \leq_{2} n D\right) \vee\left(m A>_{1} n B, m C>_{2} n D\right)\right] .{ }^{57}
\end{gathered}
$$

9. Sprawdźmy, jakie zależności zachodzą między (1), (3') i (4). Łatwo zobaczyć, że (1) $\rightarrow$ (4). Analizując poszczególne składniki koniunkcji $\neg\left(3^{\prime}\right)$ dostaniemy $\neg\left(3^{\prime}\right) \rightarrow \neg(1)$, czyli $(1) \rightarrow\left(3^{\prime}\right)$.

Wskażemy teraz taką strukturę wielkości $\mathfrak{W}=(W,+,<)$ oraz takie wielkości $A, B, C, D$, że zachodzi:

\footnotetext{
${ }^{55}$ W zależności od kontekstu, (1), (2), (3), a później - (2’), (3’) i (4), oznacza albo definicję, albo sam definiens.

${ }^{56}$ [Euklides], V, def. 7.

${ }^{57}$ Por. „rozważania przedstawione w niniejszym opracowaniu [...] zdecydowanie wskazują, że opracowanie def. 5 wynikło z istotnych badań nad tym, czym jest dysproporcja. Jest prawdopodobne, że def. 5 w rzeczywistości sformułowano jako logiczne uzupełnienie def. 7 [...]. Ale przejście od zaprzeczenia dysproporcji do proporcjonalności jest proste [immediate] i nie zostawia miejsca na coś matematycznie znaczącego"[Acerbi 2003], s. 236.
} 
(a)

$$
(A: \underset{(4)}{B::} C: D) \wedge \neg(A: B \underset{(1)}{B::} C: D) \wedge \neg\left(A: B_{(::} C: D\right),
$$

(b)

$$
\left(A: \underset{\left(3^{\prime}\right)}{B::} C: D\right) \wedge \neg(A: \underset{(1)}{B::} C: D) \wedge \neg(A: B:: C: D),
$$

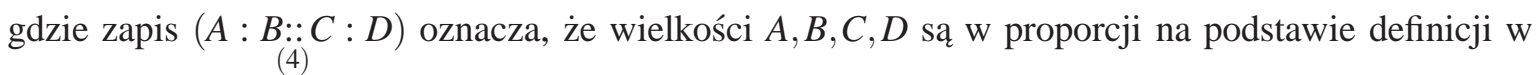
wersji (4), i odpowiednio dla pozostałych wersji.

Przyjmijmy $\mathfrak{W}=(W,+,<)$, gdzie $W$ to zbiór niestandardowych liczb rzeczywistych ograniczonych, o części standardowej dodatniej;

$$
W=\left\{x \in \mathbb{R}^{*}: s t(x)>0, \exists r \in \mathbb{R}_{+}[0<|x| \leq r]\right\},
$$

a dodawanie i porządek $w W$ są takie, jak w ciele niestandardowych liczb rzeczywistych. Stąd od razu otrzymujemy, że dodawanie jest łączne i przemienne, a porządek jest liniowy i zgodny z dodawaniem. ${ }^{58}$

$\mathrm{W} \mathfrak{W}$ spełniony jest aksjomat Archimedesa. Istotnie, jeżeli $A>B$, to $s t(A) \geq s t(B)$ i istnieje taka liczba naturalna $n$, że zachodzi $n \cdot s t(B)>s t(A)$, a wówczas $n \cdot B>A$.

Ad (a) Niech teraz $\varepsilon$ będzie dodatnią nieskończenie małą. Przyjmijmy $A=3-\varepsilon, B=2, C=3$, $D=2$. Ciało niestandardowych liczb rzeczywistych jest ciałem uporządkowanym, dlatego zachodzi $\frac{3-\varepsilon}{2}<\frac{3}{2}$. Między liczbami $\frac{3-\varepsilon}{2}$ i $\frac{3}{2}$ nie leży żadna standardowa liczba wymierna, dlatego gdy $m \neq 3 k$ lub $n \neq 2 k$, gdzie $k \in \mathbb{N}$, to

$$
\frac{3-\varepsilon}{2}<\frac{m}{n} \leftrightarrow \frac{3}{2}<\frac{m}{n} \quad \text { oraz } \quad \frac{3-\varepsilon}{2}>\frac{m}{n} \leftrightarrow \frac{3}{2}>\frac{m}{n},
$$

lub w postaci równoważnej:

$$
n \cdot(3-\varepsilon)<m \cdot 2 \leftrightarrow n \cdot 3<m \cdot 2 \text { oraz } n \cdot(3-\varepsilon)>m \cdot 2 \leftrightarrow n \cdot 3>m \cdot 2 .
$$

Gdy $m=3 k$ i $n=2 k$, to

$$
\frac{3-\varepsilon}{2}<\frac{m}{n} \wedge \frac{3}{2}=\frac{m}{n}
$$

lub w równoważnej postaci

$$
n \cdot(3-\varepsilon)<m \cdot 2 \wedge n \cdot 3=m \cdot 2 .
$$

Stąd, ostatecznie dostajemy:

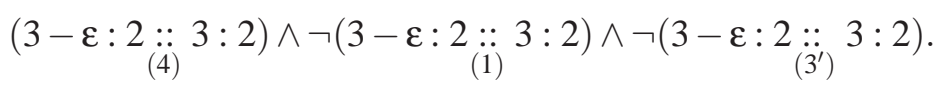

Ad (b) Teraz przyjmijmy $A=3-\varepsilon, B=2, C=3+\varepsilon, D=2$. Dla każdej pary $m, n$ zachodzi $m \cdot(3-\varepsilon) \neq n \cdot 2$ oraz $m \cdot(3+\varepsilon) \neq n \cdot 2$, zatem

$$
\left.(3-\varepsilon): 2 \underset{\left(3^{\prime}\right)}{:}(3+\varepsilon): 2\right) \text {. }
$$

Jednocześnie $2 \cdot(3-\varepsilon)<3 \cdot 2$ oraz $2 \cdot(3+\varepsilon)>3 \cdot 2$, co oznacza, że

$$
\neg(3-\varepsilon: 2: \underset{(i)}{3} 3+\varepsilon: 2) \wedge \neg(3-\varepsilon: 2:: 3+\varepsilon: 2) .
$$

Łatwo też zobaczyć, że

$$
\left(\sqrt{2}: 1 \underset{\left(3^{\prime}\right)}{ } \sqrt{3}: 1\right) \wedge \neg(\sqrt{2}: 1: \underset{(1)}{:} \sqrt{3}: 1) \wedge \neg(\sqrt{2}: 1 \underset{(4)}{::} \sqrt{3}: 1) .
$$

\subsection{Spójrzmy teraz na przykład przypadek}

\footnotetext{
${ }^{58}$ Zob. Dodatek na końcu artykułu. Dla sprawdzenia podawanych niżej nierówności wystarczy wiedzieć, że (1) $n \cdot \varepsilon<1$, dla każdej liczby naturalnej $n$, (2) nierówności są przekształcane tak, jak w dowolnym ciele uporządkowanym.
} 
(a')

$$
(A: B:: C: D) \wedge \neg(A: B:: C: D) \text {. }
$$

Otóż mamy

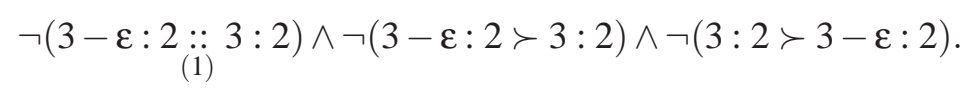

Proporcja w wersji (1) jest równoważna proporcji w wersji (2), zatem mamy także

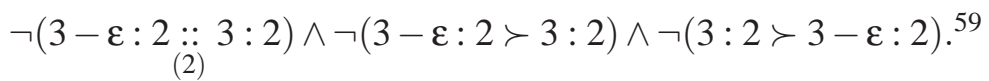

David E. Joyce w elektronicznej edycji Elementów zamieszczonej na stronach internetowych Clark University, w komentarzu do Księgi V przyjmuje definicję proporcji w wersji (2), a w związku z prawem trychotomii dla stosunków pod definicją V, def. 7 pisze:

„Z samych definicji [V.5 i V.7 - P.B.] jasno wynika, że $W: X>Y: Z$ jest sprzeczne z $W: X=Y$ : $Z$. [...] Przyjmując przechodniość [porządku stosunków- P.B.], można pokazać, że $W: X>Y: Z$ jest sprzeczne z $W: X<Y: Z[\ldots]$. (Są też dowody, które nie zależą od przechodniości.) Drugą stronę prawa trychotomii, mówiącą o tym, że zachodzi przynajmniej jeden z tych trzech przypadków, trudniej jest wykazać, a dowód zależy od potraktowania definicji V.4 jako aksjomatu porównywania. $\mathrm{W}$ istocie, bez niego rozumowanie to jest fałszywe". ${ }^{60}$

Dalej Joyce podaje dowód zapowiedzianego twierdzenia oraz przykład na to, że bez założenia aksjomatu Archimedesa prawo trychotomii nie zachodzi. ${ }^{61}$

Podany przez nas przykład pokazuje, że nie tylko „na gruncie samych definicji", czyli na gruncie logiki, bez żadnych dodatkowych założeń o strukturze $\mathfrak{W}$, ale nawet przy tych założeniach, które przyjęliśmy - liniowość porządku < oraz aksjomat Archimedesa - nie jest tak, że , $W: X>Y: Z$ jest sprzeczne z $W: X<Y: Z$ ".

Dla proporcji w wersji (4) prawo trychotomii otrzymalibyśmy wprost z definicji, zakładając, że przypadki $A: B \succ C: D$ oraz $C: D \succ A: B$ wykluczają się wzajemnie. Niestety, nawet przy tych założeniach o strukturze wielkości, które przyjęliśmy, taka sprzeczność nie zachodzi, tj. można podać przykład struktury wielkości $\mathfrak{W}$ i takich wielkości $A, B, C, D$, że

$$
(A: B \succ C: D) \wedge(C: D \succ A: B)
$$

W strukturze $\mathfrak{W}$ jest spełniony aksjomat Archimedesa, ale nie zachodzi zgodność porządku z dodawaniem. ${ }^{62}$

\footnotetext{
${ }^{59}$ Por. „Krytyka setek lat wykryła w Księdze V niedopowiedzenia - przede wszystkim, że większość, równość i mniejszość dla stosunków wykluczają się [...]. Można bez większego trudu, pozostając na gruncie myśli Księgi V usterki te usunaćc"[Kulczycki 1973], s. 200. Rzecz w tym, że nie ma zgody, co do tego, co znaczy „pozostając na gruncie myśli Księgi V". Por. także: „[W] trzeciej definicji Eudoksos wprowadza pojęcie stosunku, w czwartej wyjaśnia, co należy rozumieć przez stosunek dwóch homogenicznych wielkości, w piątej definiuje równość stosunków, w siódmej - kiedy jeden stosunek jest większy od drugiego, tym sposobem implicite pokazał, że zbiór stosunków jest zbiorem liniowo uporządkowanym [a completely ordered set]"[Nikolić 1974], s. 232.

${ }^{60}$ [Joyce 1997].

${ }^{61}$ Dowodząc prawa trychotomii, obok aksjomatu Archimedesa w wersji (A), Joyce korzysta ze zgodności dodawania wielkości z porządkiem, a wreszcie popełnia taki błąd. Mamy:

$$
\neg\left(A: B_{\ddot{2})} C: D\right) \leftrightarrow \neg(A: B \succ C: D) \wedge \exists m, n[m A=n B, m C \neq n D] \wedge \neg(B: A \succ C: D) .
$$

Natomiast zamiast $(B: A \succ C: D)$, u Joyce'a jest $(C: D \succ A: B)$. Ale z ,samych definicjińie wynika, że zachodzi: $(B: A \succ$ $C: D) \rightarrow(C: D \succ A: B)$. Mamy bowiem:

$$
(3+\varepsilon: 2 \succ 3: 2) \wedge(2: 3+\varepsilon \ddot{(\ddot{4})} 2: 3) .
$$

${ }^{62}$ [Błaszczyk 2007].
} 
W przypadku definicji (3’) nie zachodzi nawet sprzeczność między proporcją a nierównością. Spójrzmy bowiem na przypadek

(b')

$$
\left(A: \underset{\left(3^{\prime}\right)}{::} C: D\right) \wedge \neg(A: B:: C: D) \text {. }
$$

Przyjmijmy, że wielkości $1, \sqrt{2}, \sqrt{3}$ należą do struktury $\mathfrak{W}=\left(\mathbb{R}_{+},+,<\right)$. W tej strukturze spełniony jest Aksjomat Archimedesa i w wersji (A), i w wersji (E), i zgodność porządku z dodawaniem, i wszystkie inne założenia o strukturze wielkości, jakie można znaleźć w Księdze V. Teraz mamy:

$$
\left(\sqrt{3}: 1: \underset{\left(3^{\prime}\right)}{ } \sqrt{2}: 1\right) \text { oraz } \sqrt{3}: 1 \succ \sqrt{2}: 1 \text {. }
$$

Druga zależność zachodzi dlatego, że

$$
\frac{\sqrt{3}}{1}>\frac{3}{2} \geq \frac{\sqrt{2}}{1}, \text { czyli } 2 \cdot \sqrt{3}>3 \cdot 1 \wedge 3 \cdot 1 \geq 2 \cdot \sqrt{2} .
$$

9.2. Wielkości współmierne i niewspółmierne. Definicja:

„Those magnitudes are said to be commensurable which are measured by the same measure, and those incommensurable which cannot have any common measure". ${ }^{63}$

I cztery twierdzenia

"Commensurable magnitudes have to one another the ratio which number has to a number", 64

„If two magnitudes have to one another the ratio which a number has to a number, then the magnitudes are commensurable", 65

„Incommensurable magnitudes do not have to one another the ratio which number has to a number", ${ }^{66}$

"If two magnitudes do not have to one another the ratio which a number has to a number, then the magnitudes are incommensurable". ${ }^{67}$

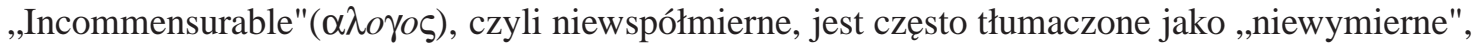
gdzie „niewymierneóznacza liczbę rzeczywistą. W kontekście powyższych przykładów pokazuje się, że jest to daleko posunięta nadinterpretacja. ${ }^{68}$

Po drugie, i to jest ważniejsze. W dowodzie twierdzenia X.5 fakt, iż A jest taką samą wielokrotnością $C$, jak $m$ jest wielokrotnością jedności Euklides przedstawia w formie proporcji $C: A:: m: 1 \mathrm{i}$ stosuje do niej twierdzenia z Księgi V. Robert Simson jako pierwszy zauważył, że Euklides przyjmuje w tym miejscu definicję proporcji z Księgi VII, mianowicie:

„Numbers are proportional when the first is the same multiple, or the same part, or the same parts, of the second that the third is of the fourth". ${ }^{69}$

\footnotetext{
${ }^{63}$ [Euklides], X, def. 1.

${ }^{64}$ [Euklides], X, tw. 5.

65 [Euklides], X, tw. 6.

${ }^{66}$ [Euklides], X, tw. 7.

${ }^{67}$ [Euklides], X, tw. 8.

${ }^{68}$ Według Heath’a właściwym tłumaczeniem $\alpha \lambda o \gamma o \varsigma$ byłoby „,(in)expressible”, a nie „,(ir)rational". Zob. [Heath 1956], I,

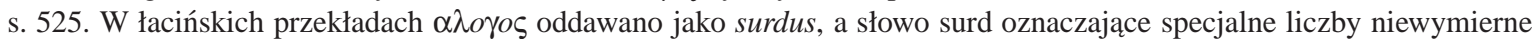
do dzisiaj funkcjonuje w języku angielskim. Zob. [Fowler 1992], ss. 241-243 oraz [Claphan, Nicholson 2005], s. 447.

${ }^{69}$ [Euklides], VII, def. 20. W sprawie pojęć ,part"i „,partsźob. wyżej pkt. 5.1.
} 
Aby wypełnić tę ,lukę"w wywodzie Euklidesa Simson dowodzi, że wielkości, które są proporcjonalne w sensie definicji VII.20 są też proporcjonalne w sensie definicji V.5, mianowicie

"If the first be the same multiple of the second, or the same part of it, that the third is of the fourth, the first is to the second as the third is to the fourth". ${ }^{70}$

W dowodzie Simson przyjmuje wprost sformułowane założenie $m A<n A \rightarrow m<n$. Można jednak wskazać taką strukturę wielkości, w której założenie to nie jest spełnione,a jednocześnie jest tak, że (przy każdej interpretacji definicji V.5)

$$
(A=m C, B=n C) \wedge \neg(A: B:: m: n){ }^{71}
$$

Odrębnym zagadnieniem jest to, na ile uprawnione jest traktowanie liczb naturalnych jako wielkości i porównywanie stosunków liczb ze stosunkami wielkości geometrycznych. W wielu komentarzach czyni się tak bez żadnych zastrzeżeń. Od historyków matematyki greckiej można natomiast dowiedzieć się, że „Euklides [...] nigdy nie traktuje liczb jako wielkości". ${ }^{72}$

9.3. W odniesieniu do zdefiniowanej w pkt. 9. struktury wielkości $\mathfrak{W}$ możemy powiedzieć, że na podstawie definicji (1) można rozróżnić tylko takie stosunki $A: B$ i $C: D$, które wzięte jako liczby $\frac{A}{B} \mathrm{i}$ $\frac{C}{D}$ są takie, że jedna z nich jest standardową liczbą wymierną lub są takie, że $\frac{A}{B}<\frac{p}{q}<\frac{C}{D}$, dla pewnej standardowej liczby wymiernej $\frac{p}{q}$. Nie można natomiast odróżnić liczb leżących nieskończenie blisko tej samej standardowej liczby wymiernej, ale jednocześnie większych lub jednocześnie mniejszych od niej, np.

$$
3+\varepsilon: 2 \underset{(:)}{: 3} 3+\varepsilon^{2}: 2 .
$$

Nie można też odróżnić liczb leżących nieskończenie blisko standardowej liczby niewymiernej, np.

$$
(\sqrt{3}-\varepsilon: \underset{(1)}{2::} \sqrt{3}: 2) \wedge(\sqrt{3}+\varepsilon: \underset{(1)}{2::} \sqrt{3}: 2) \wedge(\sqrt{3}-\varepsilon: \underset{(1)}{2:: \sqrt{3}}+\varepsilon: 2){ }^{73}
$$

Ostatnie przykłady pokazują, że niewłaściwe jest interpretowanie stosunku po prostu jako liczby rzeczywistej, bo jaką liczbą rzeczywistą miałoby być stosunek $\sqrt{3}-\varepsilon: 2 ?^{74}$

Czy ogólniej, zdarza się, że stosunek $A: B$ jest interpretowany jako iloraz $\frac{A}{B}$, a dalej, że proporcja jest równością stosunków-ilorazów. To błędna interpretacja. Po pierwsze, w strukturze wielkości nie jest określone dzielenie, po drugie, nawet gdy można określić dzielenie wielkości - tak jak w rozważanym przypadku - to proporcja nie jest równością stosunków-ilorazów, bo mamy na przykład

$$
(\sqrt{3}-\varepsilon: 2:: \underset{(1)}{ } \sqrt{3}: 2) \wedge\left(\frac{\sqrt{3}-\varepsilon}{2} \neq \frac{\sqrt{3}}{2}\right) .
$$

\footnotetext{
${ }^{70}$ Informacje te podajemy za komentarzem Hetah'a do twierdzenia X.5. Zob. [Heath 1956], III, s. 25. Twierdzenie Simsona cytujemy za [Heath 1956], II, s. 126. Dowód tego twierdzenie znajduje się w [Heath 1956], II, ss. 126-128.

${ }^{71}$ Zob. [Błaszczyk 2007].

${ }^{72}$ [Artmann 1991], s. 6. Zob. także: 51 Zob. także. „Często się zauważa, że mimo ogólności [teorii proporcji - P.B.] Euklides wprowadza w Księdze VII specjalne pojęcie proporcjonalności liczb (naturalnych) i nie próbuje nawet pogodzić tych dwóch różnych definicji"[Artmann 1991], s. 6, „Znamienne, że Euklides dwukrotnie rozwija teorię proporcji: w Księdze V, w odniesieniu do wielkości w ogóle, i w Księdze VII w odniesieniu do szczególnego przypadku - liczb. Ten drugi wykład, odnosząc się jedynie do wielkości współmiernych, może być po prostu teorią proporcji z okresu zanim została ona rozwinięta przez Eudoksosa. [...] zupełnie naturalnie rodzi się pytanie, dlaczego Euklides nie oszczędził sobie tylu powtórzeń i nie potraktował liczb po prostu jako szczególnego przypadku wielkości i zamiast dowodzić raz jeszcze tych samych twierdzeń dla liczb, nie odsyła do odpowiednich ogólniejszych twierdzeń Księgi V?"[Heath 1956], II, s. 113.

${ }^{73}$ Por. „Pierwszy aksjomat [aksjomat Archimedesa w wersji (E) - P.B.] gwarantuje, że dwa różne odcinki nie są w tym samym stosunku do ustalonego odcinka jednostkowego"[Weyl 1949], s. 39.

${ }^{74}$ Por. np. ,Stosunek Eudoksosa $a: b$ wielkości archimedesowych $a$ oraz $b$ i przekrój Dedekinda $\left(A_{1}, A_{2}\right)$ systemu dodatnich liczb wymiernych są określoną liczbą rzeczywistą"[Nikolić 1974], s. 238-239, przy czym „wielkości archimedesowe", to wielkości spełniające aksjomat Archimedesa w wersji (E), zob. [Nikolić 1974], s. 229.
} 
9.4. Wiemy już, że w zdefiniowanej w pkt. 9. strukturze $\mathfrak{W}$ jest spełniony aksjomat Archimedesa w wersji (E). Pokażemy, że w strukturze tej nie jest spełniony aksjomat Archimedesa w wersji (A) ${ }^{75}$ Niech $\varepsilon$ będzie dodatnią nieskończenie małą. Wówczas jest $2<2+\varepsilon$, a jednocześnie dla każdego $n$ zachodzi $n \cdot(2+\varepsilon-2)<2$ oraz $n \cdot(2+\varepsilon-2)<2+\varepsilon$. Wynik ten nie jest owszem jednoznaczny, bo $(2+\varepsilon-2)=\varepsilon \notin W$, ale tym samym i aksjomat Archimedesa w wersji (A) nie jest jednoznaczny.

9.5. Z aksjomatem Archimedesa wiązane jest twierdzenie X.1, wykorzystywane w Księdze XII:

„Two unequal magnitudes being set out, if from the greater there be subtracted a magnitude greater than the half, and from that which is left the magnitude greater than its half, and if this process be repeated continually, there will be left some magnitude which will be less than lesser magnitude set out". ${ }^{76}$

Przyjmując, że dla wielkości $A$, ,a magnitude greater than the half"to $q A$, gdzie $q$ jest taką liczbą wymierną, że $\frac{1}{2}<q<1$, to w strukturze wielkości zdefiniowanej w pkt. 9. prawdziwe jest twierdzenie X.1.

9.6. Spójrzmy na zdefiniowaną w punkcie 9. strukturę wielkości z ogólniejszej perspektywy. W strukturze $\mathfrak{W}$ spełniony jest warunek (E), a nie jest spełniony warunek (A). W ciele uporządkowanym $\mathfrak{F}=(F,+, \cdot, 0,1,<)$ nie odróżnia się warunków (E) i (A), a warunek Archimedesa jest tak definiowany:

$$
\forall a, b \exists n[(0<a<b) \rightarrow n a>b] .
$$

Pokazuje się, że w ciele $\mathfrak{F}$ aksjomat Archimedesa jest też równoważny warunkowi: zbiór ułamków $\mathbb{Q}_{F}$ ciała $\mathfrak{F}$ jest gęsty w zbiorze $(F,<)$, tj.

$$
\forall a, b \in F \exists q \in \mathbb{Q}_{F}[a<b \rightarrow a<q<b] .{ }^{77}
$$

Z uwagi na tę własność zachodzi istotna różnica między ciałem liczb rzeczywistych $\mathfrak{R}=(\mathbb{R},+, \cdot, 0,1,<$ ) a ciałem niestandardowych liczb rzeczywistych $\mathfrak{R}^{*}=\left(\mathbb{R}^{*},+, \cdot, 0,1,<\right)$ : zbiór liczb wymiernych $\mathbb{Q}$ jest gęsty w $(\mathbb{R},<)$, zbiór $\left\{q^{*}: q \in \mathbb{Q}\right\}$ nie jest gęsty ani w zbiorze $\left(\mathbb{R}^{*},<\right)$, ani w zbiorze niestandardowych liczb ograniczonych. ${ }^{78}$ Podane wyżej przykłady eksploatowały właśnie tę różnicę.

Pytaniem otwartym pozostaje, czy można wskazać taką strukturę wielkości $\mathfrak{W}=(W,+,<)$, w której spełniony jest warunek (A) i w której zachodzą różnice między definicjami w wersji (1), (3’) i (4).

9.7. Przypomnijmy, że jedyne założenia o strukturze wielkości $\mathfrak{W}=(W,+,<)$, jakie przyjęliśmy to łączność i przemienność dodawania, liniowość porządku oraz aksjomat Archimedesa w wersji wprost zapisanej w Elementach, tj. w wersji (E). W komentarzach, o strukturze wielkości w Elementach przyjmuje się ponadto:

(1) $a<b \rightarrow b-a \in W,{ }^{79}$

(2) $a \in W \rightarrow \forall n \in \mathbb{N}[n a \in W],{ }^{80}$

\footnotetext{
${ }^{75}$ Tak więc w strukturze $\mathfrak{W}$ jest $(E) \wedge \neg(A)$. Por.: ,praktycznie jest ona [definicja V.4 - P.B.] równoważna zasadzie leżącej u podstaw metody wyczerpywania i znanej jako aksjomat Archimedesa"[Heath 1981], s. 385, „Według Archimedesa, aksjomat ten (dokładnie równoważne mu zdanie) był stosowany przez Eudoksosa"[Klein 1972], s. 81.

${ }^{76}$ [Euklides], X, tw. 1.

${ }^{77}$ Zob. [Cohen-Ehrlich 1963], s. 87-88.

${ }^{78}$ Zob. Dodatek.

${ }^{79}$ Założenie to występuje u Heath’a m.in. przy transkrypcji definicji V.15 i V.16 na język algebraiczny. Definicję „A conversion of a ratio means taking the antecedent to the excess by which the antecedent exceeds the consequent"[Euklides], V, def. 16 - Heath tak objaśnia: „Konwersja stosunku oznacza, że np. w miejsce stosunku $A$ do $B$, brany jest stosunek $A$ do $A-B$ (zakładając, że $A$ jest większe od $B$ )"[Heath 1956], II, s. 135.

${ }^{80}$ Takie założenie o strukturze wielkości znajduje Dedekind; zob. wyżej pkt. 6.5.
} 
(3) $\forall n \in \mathbb{N}[a<b \leftrightarrow n a<n b],{ }^{81}$

(4) $\forall n \in \mathbb{N}[n a<m b \rightarrow n<m] .{ }^{82}$

Można pokazać, że nie wszystkie wielkości podane w tabeli w punkcie 6. spełniają założenia (3) i (4).

9.8. Howard Stein i Bob Hale rozwijając, jak sami przyznają, pomysł Gottloba Frege, że teoria liczb rzeczywistych winna być oparta na teorii wielkości, budują na gruncie definicji proporcji swoje teorie wielkości. ${ }^{83}$ Przyjmują przy tym, z większym lub mniejszym respektem dla faktów historycznych, swoiste założenia. I tak Stein charakteryzuje strukturę wielkości następującymi warunkami: ${ }^{84}$

(1) dodawanie jest łączne i przemienne,

(2) dla dowolnych $a, b \in W$ zachodzi dokładnie jeden ze składników alternatywy:

$$
\exists c \in W[a=b+c] \vee a=b \vee \exists c \in W[b=a+c],
$$

(3) $a<b \rightarrow \exists c \in W[b=a+c]$,

(4) $\exists n, m \in \mathbb{N}[m a>b \wedge n b>a] .{ }^{85}$

Bob Hale charakteryzuje strukturę wielkości z większą swobodą, mianowicie:

(1) dodawanie jest łączne i przemienne,

(2) dla dowolnych $a, b \in W$ zachodzi dokładnie jeden ze składników alternatywy:

$$
\exists c \in W[a=b+c] \vee a=b \vee \exists c \in W[b=a+c],
$$

(3) $a<b \rightarrow \exists c \in W[b=a+c]$,

(4) $\exists n \in \mathbb{N}[n a>b]$,

(5) $\forall a, b, c \in W \exists q \in W[a: b:: c: q],{ }^{86}$

(6) dla każdego niepustego i ograniczonego z góry podzbioru $S \subset W$, istnieje w $W$ kres górny zbioru $S .{ }^{87}$

\footnotetext{
${ }^{81}$ Takie założenie przyjmuje w swojej edycji Elementów Robert Simson uzupełniając „luki"w dowodach twierdzeń X.5 i X.6; zob. [Heath 1956], II, ss. 130-131, 157. Dane bibliograficzne edycji Simsona podajemy wyżej w przypisach, w punkcie 3. Komentarze Simsona są bardzo często przytaczane przez Heath'a. Nawet na tle dzisiejszych komentarzy, kiedy - jak się sądzi - wszystko już wiemy o Elementach, uwagi Simson'a są niezwykle przenikliwe. Dla przykładu, Simson, na blisko sto lat przed Hilbertem, sformułował aksjomaty opisujące zgodność porządku z dodawaniem wielkości, podczas gdy po dzień dzisiejszy w większości komentarzy w ogóle nie zauważa się tej kwestii.

${ }^{82}$ Takie założenie stosuje w swoich dowodach twierdzeń z księgi V Elementów Jerzy Mioduszewski; zob.: „Jeśli $a: b$ jest (dowolną) proporcją [...]. Mamy $m \cdot p \cdot a<m \cdot q \cdot b=m \cdot q \cdot a$, skąd $m \cdot p<m \cdot q$ "[Mioduszewski 1996], s. 64.

${ }^{83}$ Zob. [Hale 2000], [Stein 1990].

${ }^{84}$ Ściśle rzecz biorąc w ujęciach tych strukturą wielkości jest struktura $(W,+)$, a porządek wielkości jest definiowany: $a<b \leftrightarrow d f \exists c \in W[b=a+c]$. Jednocześnie o porządku tym przyjmuje się - a nie dowodzi, jak należałoby oczekiwać że spełnia aksjomat Archimedesa. Dodatkową trudność stanowi to, że u Hale'a i Stein'a istotne jest pojęcie stosunku. I tak np. Stein pisze, że definicja V.5 „,charakteryzuje stosunki"[Stein 1990], s. 169. Aby rozwikłać te zapętlenia potrzebne jest odrębne opracowanie. Należy więc przyjąć, że podana charakterystyka jest interpretacją prac Hale'a i Stein'a.

${ }^{85}$ Zob. [Stein 1990], ss. 168-169.

${ }^{86}$ Warunek ten jest nazywany założeniem o istnieniu czwartej proporcjonalnej i jest wykorzystywany do definiowania działań w zbiorze stosunków.

${ }^{87}$ Zob. [Hale 2000], ss. 106-108.
} 
Hale dowodzi, że jeżeli porządek wielkości jest zupełny (w sensie Dedekinda), to i porządek w zbiorze stosunków $W \times W /::$ też jest zupełny, ale nie podaje żadnej definicji porządku stosunków. A dalej, twierdzi, iż można pokazać, że jeżeli $W \times W /::$ oraz $W^{\prime} \times W^{\prime} /:$ są strukturami spełniającymi warunki (1)-(6), to są izomorficzne, tak że $W \times W /::=W^{\prime} \times W^{\prime} /:$, tzn. zbiór stosunków wielkości z $W$ jest identyczny ze zbiorem stosunków wielkości z $W^{\prime} .88$

Prace neologików Stein'a i Hale'a są wzorcowym przykładem na to, jak próbuje się wymusić na teorii proporcji podobieństwo do liczb rzeczywistych. Istotny jest tu warunek zgodności dodawania wielkości z porządkiem wielkości. ${ }^{89}$ Bez wchodzenia w szczegóły można powiedzieć tyle: $\mathrm{O}$ porządku liczb rzeczywistych można pokazać, iż jest to jedyny porządek zgodny ze strukturą algebraiczną ciała liczb rzeczywistych, o porządku wielkości definiowanym przez Stein'a i Hale'a nie da się tego pokazać. Po drugie, i to jest ważniejsze, warunek zgodności porządku z działaniami wyklucza z rozważań niektóre wielkości ujęte w tabeli podanej w punkcie 6.

10. Są takie komentarze, w których proporcja jest opisywana językiem teorii relacji. ${ }^{90}$ I tak wprost z definicji ma wynikać zwrotność i symetryczność proporcji, a na podstawie twierdzenia V.11:

„Ratios which are the same with the same ratio are also the same with one another", ${ }^{91}$

przyjmuje się jej przechodniość. Na tej podstawie przyjmuje się, że proporcja jest relację równoważności. Czy słusznie? Zgodnie z literą Elementów proporcja nie jest relacją zwrotną:

„A proportion in three terms is the least possible". ${ }^{92}$

Tak więc proporcja nie jest relacją zwrotną nie dlatego, że istnieje taka para wielkości $A, B$, że nie zachodzi $A: B:: A: B$, ale dlatego, że na mocy definicji w proporcji muszą wystąpić co najmniej trzy różne wielkości $A, B, C .^{93}$

10.1. Zostawiając na stronie fakty historyczne, spróbujmy sprawdzić, czy istotnie proporcja jest relacją zwrotną. ${ }^{94}$

Wprowadzając pojęcie struktury wielkości możemy odróżnić wielkości $A, B$ rozumiane jako elementy zbioru $W$, od wielkości $A, B$ rozumianych jako elementy różnych struktur $(W,+,<)$ i $\left(W,+^{\prime},<^{\prime}\right)$. Wówczas wielkości $A, B$, o ile należą do różnych struktur, są wielkościami różnego rodzaju.

Przyjmijmy teoriomnogościowe rozumienie relacji i postawy podstawowe pytanie: jeżeli proporcja jest relacją, to w jakim zbiorze? ${ }^{95}$ Znajdujemy dwie odpowiedzi:

\footnotetext{
${ }^{88}$ Zob. [Hale 2000], s. 108.

${ }^{89}$ Zob. „Zachodzi też ważne twierdzenie: jeżeli $a<b$, to $a+c<b+c$ "[Stein 1990], s. 167.

${ }^{90}$ Zob. „W twierdzeniu V.11 mówi się [...]. Zatem proporcjonalność stosunków jest przechodnia [...]. Z definicji proporcjonalności wynika także jej symetryczność [...]. Dlatego proporcjonalność jest relacją typu równości [...]. Wobec tego wszystkie pary wielkości rozbijają się na klasy par proporcjonalnych jedna do drugiej, i nowy obiekt występuje jako ta cecha ogólna, która charakteryzuje wszystkie pary wielkości pewnej klasy"[Baszmakowa 1975], ss. 106-107, „Równość proporcji jest zwrotna, symetryczna i przechodnia, co wynika natychmiast z jej określenia"[Mioduszewski 1996], s. 64, „Zwrotność i symetryczność relacji Eudoksosa wynika w sposób oczywisty z samej definicji. Jeżeli zaś idzie o przechodniość, to Euklides przyjmuje trud dowodu [...]"[Stein 1990], s. 169.

${ }^{91}$ [Euklides], V, tw. 11.

92 [Euklides], V, def. 8.

${ }^{93}$ Por. „Można przyjąć, że zwrotność i symetria wydawały się Grekom tak oczywiste, że nie uważali za konieczne, aby to jakoś szczególnie podkreślać"[Nikolić 1974], s. 232.

${ }^{94}$ Zob. „Pojęcie wielkości, według Eudoksosa, obejmuje zarówno liczby, jak i wielkości ciagłe: odcinki, pola, objętości"[Baszmakowa 1975], s. 105, „Warunek identyczności stosunków jest tak sformułowany, że dopuszcza, iż jeden i ten sam stosunek może być zarazem stosunkiem wielkości różnego rodzaju [...] takich jak masy i długości"[Hale 2000], s. 107, „Weźmy pod uwagę dwie pary i wielkości, tego samego rodzaju w każdej parze, chociaż niekoniecznie tego samego rodzaju w obu parach"[Mioduszewski 1996], s. 63-64, ,Jeżeli $a$ i $b$ są wielkościami rodzaju $Q$ [...] i jeżeli $Q^{\prime}$ jest gatunkiem wielkości, zaś $c$ i $d$ pewnymi elementami $Q^{\prime}$ [...]"[Stein 1990], s. 168.

${ }^{95}$ Przyjmujemy tu naiwne rozumienie zbioru, w szczególności nie odróżniamy klasy od zbioru.
} 
(B) proporcja jest :: relacją w zbiorze par wielkości $(A, B),{ }^{96}$

(S) proporcja jest :: relacją w zbiorze stosunków. ${ }^{97}$

Ad (B). Przyjmując, że dany jest zbiór wszystkich struktur wielkości $\left\{\left(W_{t},+_{t},<_{t}\right): t \in T\right\}$, dziedziną relacji proporcji :: byłby zbiór $\bigcup W_{t} \times \bigcup W_{t}$, a para $(A, B)$ może wówczas należeć do różnych struktur. Pokażemy niżej, że przy takiej interpretacji proporcja nie jest relacją zwrotną.

Ad (S). W tej interpretacji przez stosunek wielkości $A, B$ rozumienie się parę $(A, B)_{W_{t}}$, gdzie para $(A, B)$ jest opatrzona indeksem $W_{t}$, wtedy gdy $A, B$ należą do struktury $\left(W_{t},+_{t},<_{t}\right) .{ }^{98}$ Przyjmując, że dany jest zbiór wszystkich stosunków $\Lambda$, proporcja miałaby być relację w zbiorze $\Lambda \times \Lambda$. Pokażemy niżej, że przy takiej interpretacji proporcja nie jest relacją zwrotną.

Przyjmując zaproponowane przez nas rozumienie struktury wielkości, proporcję :: można interpretować jako relację, ale w $\left\{\left((A, B),\left(W_{t},+_{t},<_{t}\right)\right): t \in T\right\}$, tj. wtedy, gdy para $(A, B)$ jest indeksowana struktura, $\left(W_{t},+_{t},<_{t}\right)$ do której należy, a nie tylko dziedziną tej struktury $W_{t}$, tak jak w przypadku (S).

10.2. Pokażemy teraz, że zarówno w interpretacji (B), jak i (S) proporcja nie jest relacją zwrotną. Niech $(\mathbb{R},+, \cdot, 0,1,<)$ będzie ciałem uporządkowanym w sposób ciągły. Można pokazać, że ciało $(\mathbb{R}, \oplus, \cdot, 0,1,<)$, gdzie

$$
a \oplus b=(\sqrt[3]{a}+\sqrt[3]{b})^{3},
$$

a porządek w obydwu ciałach jest ten sam, jest ciałem uporządkowanym w sposób ciągły.

Przyjmujemy dwie struktury wielkości: $\mathfrak{W}_{1}=\left(\mathbb{R}_{+},+,<\right)$oraz $\mathfrak{W}_{2}=\left(\mathbb{R}_{+}, \oplus,<\right)$. W strukturze $\mathfrak{W}_{2}$ jest $a \oplus a=2^{3} \cdot a$, czy ogólnie $n a=n^{3} \cdot a$. Zatem i $\mathfrak{W}_{1}$ i $\mathfrak{W}_{2}$ są strukturami wielkości archimedesowych. ${ }^{99} \mathrm{~W}$ strukturze $\mathfrak{W}_{1}$ wyrażenie $m A>n B$ oznacza $\frac{A}{B}>\frac{n}{m}$, gdzie kreska ułamkowa jest rozumiana jako działanie odwrotne do mnożenia, zaś w strukturze $\mathfrak{W}_{2}$ wyrażenie to oznacza $\frac{A}{B}>\frac{n^{3}}{m^{3}}$. Dla celów niniejszego przykładu definicję proporcji przyjmujemy w wersji (2). Pokażemy, że

$$
\neg(2: 1: \underset{(2)}{2: 1)} \text {. }
$$

Istotnie, mamy bowiem

$$
\begin{gathered}
\neg(2: 1: \underset{(2)}{(2)}: 1) \leftrightarrow \exists m, n \in \mathbb{N} \\
\left(\frac{2}{1}>\frac{m}{n}, \frac{2}{1} \leq \frac{m^{3}}{n^{3}}\right) \vee\left(\frac{2}{1}=\frac{m}{n}, \frac{2}{1} \neq \frac{m^{3}}{n^{3}}\right) \vee\left(\frac{2}{1}<\frac{m}{n}, \frac{2}{1} \geq \frac{m^{3}}{n^{3}}\right) .
\end{gathered}
$$

Aby to pokazać, wystarczy przyjąć $m=2, n=1$. Taki sam wynik otrzymamy, gdy parze $(2,1)$ dodamy indeks $\mathbb{R}_{+}$, tj. $(2,1)_{\mathbb{R}_{+}}$. Zauważmy przy tym, że w strukturze $\mathfrak{W}_{1}$ wielkości 2 i 1 są współmierne, a w strukturze $\mathfrak{W}_{2}$ - niewspółmierne.

11. Jak powiedzieliśmy, powszechnie podkreśla się, często czyniąc z tego jedną z zalet teorii Eudoksosa, że wielkości występujące w proporcji muszą być parami tego samego rodzaju. Są jednak i takie komentarze, w których z uwagi na domniemaną atrakcyjność interpretacji pomija się to zastrzeżenie. ${ }^{100} \mathrm{~W}$ tym punkcie pokażemy, że ignorowanie tego założenia prowadzi do błędu. Kwestia ta związana jest z twierdzeniem o przestawianiu wyrazów w proporcji:

\footnotetext{
${ }^{96}$ Zob. [Baszmakowa 1975], s. 106-107.

${ }^{97}$ Zob. [Stein 1990], ss. 167-169, np. , $(a: b)_{Q^{-}}$stosunek $a$ do $b$ w $Q^{\prime \prime}$, gdzie $Q$ jest rodzajem wielkości.

${ }^{98}$ Para $(A, B)_{W_{t}}$ to de facto para $\left((A, B), W_{t}\right)$.

${ }^{99}$ Skądinąd wynika to także z ciągłości porządku $<$.

100, ,[M]ożna wykazać, że istnieje stosunek pola koła do pola kwadratu [zbudowanego - P.B.] na jego średnicy (pozostając ściśle na gruncie zasad Euklidesa)"[Stein 1990], s. 179, „W twierdzeniach samego Euklidesa możliwe jest jednak wyjście poza granice ciała pitagorejskiego. Ponieważ, na przykład, z proporcji $a: b=c: d$ wynika proporcja $a: c=b: d$, z twierdzenia o proporcjonalności kół do kwadratów zbudowanych na nich średnic [powinno być: do kwadratów zbudowanych na ich średnicach - P.B.] wynika, że można mówić o stosunku koła do opisanego kwadratu, a jest on równy $\frac{\pi}{4}$ "[Baszmakowa 1975], s. 122.
} 
„If four magnitudes be proportional, they will also be proportional alternately,"101

symbolicznie:

$$
A: B:: C: D \rightarrow A: C:: B: D .
$$

W dowodzie występuje założone, że wielkości $A, B, C, D$ są tego samego rodzaju, gdyż porównywane są wielokrotności $n A, m C$ oraz $n B, m D$. Czytamy bowiem:

„For of $A, B$, let equimultiples $E, F$ be taken, and of $C, D$ other, chance, equimultiples $G, H$. [...] Therefore, if is in excess of , is also in excess of , if equal, equal, if less, less". ${ }^{102}$

W komentarzach, w których bagatelizuje się założenie o jednorodności wielkości, wskazuje się zwykle dowód twierdzenia XII.2, gdzie zmieniane są wyrazy proporcji, w której występują wielkości różnego rodzaju. Twierdzenie to brzmi:

„Circles are to one another as the squares on their diameters". ${ }^{103}$

W dowodzie twierdzenia występuje proporcja $S_{1}: S:: P_{1}: P_{2}$, gdzie $S$ i $S_{1}$ to koła, a $P_{1}$ i $P_{2}$ to wielokaty. Proporcja ta jest przekształcana do postaci $S: P_{2}:: S: P_{1}$, tak że po lewej i prawej stronie proporcji występują stosunki wielkości różnych rodzajów (przyjmując podział wielkości przedstawiony w punkcie 6.).

11.1. Raz jeszcze pozostawiając na stronie fakty historyczne, pokażemy, że w twierdzeniu o zmianie wyrazów proporcji konieczne jest założenie, że wielkości występujące w proporcji są tego samego rodzaju. ${ }^{104}$

Tak jak wyżej przyjmujemy dwie struktury wielkości: $\mathfrak{W}_{1}=\left(\mathbb{R}_{+},+,<\right)$oraz $\mathfrak{W}_{2}=\left(\mathbb{R}_{+}, \oplus,<\right)$. Definicje proporcji przyjmujemy w wersji (2).

Niech wielkości $A=\sqrt{3}, B=1$ należą do struktury $\mathfrak{W}_{1}$, a wielkości $C=2, D=1$ - do struktury $\mathfrak{W}_{2}$. Jest $\neg(\sqrt[3]{2}: 1 \ddot{\because(2)} 2: 1)$. Istotnie, można sprawdzić, że w ciele liczb rzeczywistych dla dowolnej pary liczb naturalnych $(m, n)$ zachodzi:

$$
\left.\left(\frac{\sqrt[3]{2}}{1}>\frac{m}{n} \rightarrow \frac{2}{1}>\frac{m}{n}\right) \wedge\left(\frac{\sqrt[3]{2}}{1}=\frac{m}{n} \rightarrow \frac{2}{1}=\frac{m}{n}\right) \wedge\left(\frac{\sqrt[3]{2}}{1}<\frac{m}{n} \rightarrow \frac{2}{1}<\frac{m}{n}\right)\right],
$$

co oznacza, że $(\sqrt[3]{2}: 1: \underset{(2)}{2} 2: 1) \cdot{ }^{105}$

Pokażemy teraz, że

$$
\neg(\sqrt[3]{2}: 2 \underset{(2)}{2: 1: 1)} \text {. }
$$

W tym celu wystarczy sprawdzić, że dla pary $m=3, n=4$ zachodzi:

$$
\left.\left(\frac{\sqrt[3]{2}}{2}>\frac{m}{n} \wedge \frac{1}{1} \leq \frac{m^{3}}{n^{3}}\right) \vee\left(\frac{\sqrt[3]{2}}{2}=\frac{m}{n} \wedge \frac{1}{1} \neq \frac{m^{3}}{n^{3}}\right) \vee\left(\frac{\sqrt[3]{2}}{2}<\frac{m}{n} \wedge \frac{1}{1} \geq \frac{m^{3}}{n^{3}}\right)\right]
$$

12. W przykładach z punktów 10.2 i 11.1 przyjęliśmy definicję proporcji w wersji (2), ale takie same wyniki otrzymamy przyjmując definicję w wersji ( $\left.3^{\prime}\right)$, czy (4) i dobierając odpowiednie podstawienia.

Nie potrafimy rozstrzygnąć na gruncie filologiczno-historycznym, która wersja definicji V.5 jest właściwa. Przyjmujemy, że badania samego tekstu Elementów nie dają jednoznacznej odpowiedzi.

\footnotetext{
${ }^{101}$ [Euklides], V, tw. 16.

${ }^{102}$ [Euklides], V, tw. 16.

${ }^{103}$ [Euklides], XII, tw. 2. Symbolicznie: $S_{1}: S_{2}:: d_{1}^{2}: d_{2}^{2}$, gdzie $S_{1}$ jest kołem o średnicy $d_{1}, S_{2}$ jest kołem o średnicy $d_{2}$, $d_{1}^{2}$ jest kwadratem o boku $d_{1}, d_{2}^{2}$ jest kwadratem o boku $d_{2}$.

${ }^{104}$ Por. "Jeśli $a: b=c: d$, to $a: c=b: d$ "[Mioduszewski 1996], s. 66. Twierdzenie to podane jest z dowodem.

${ }^{105}$ Por. ,Jeśli $a: b=c: b$, to $a=c$ "[Mioduszewski 1996], s. 66.
} 
Pewne wskazówki można natomiast otrzymać biorąc pod uwagę twierdzenia Księgi V. Weźmy dla przykładu jedno z ważniejszych:

„Of unequal magnitudes, the greater has to the same a greater ratio than the less has; and the same has to the less a greater ratio than it has to the greater". ${ }^{106}$

W pkt. 6 rozważaliśmy strukturę $\left(\mathbb{R}_{+},+,<\right)$. Są w niej spełnione wszystkie założenia o strukturze wielkości, jakie można znaleźć w dowodach twierdzeń Księgi V. W strukturze tej mamy

$$
(\sqrt{3}>\sqrt{2}) \wedge\left(\sqrt[3]{2}: 1 \underset{\left(3^{\prime}\right)}{:} \sqrt{2}: 1\right)
$$

co - jak można by sądzić - poddaje w wątpliwość poprawność transkrypcji definicji proporcji w wersji $\left(3^{\circ}\right)$. Tym niemniej rzecz wcale nie jest oczywista i ostatecznie rozstrzygnięcie zależy od przyjętego celu: czy jest nim interpretacja historycznego tekstu, czy teoria proporcji. Przyjmijmy, że interesuje nas teoria proporcji.

We współczesnej geometrii przez teorię proporcji rozumie się teorię figur podobnych, a więc zawartość Księgi VI. Za podstawowe twierdzenie teorii figur podobnych uznawane jest twierdzenie odpowiadające twierdzeniu VI.2

"If a straight line is drawn parallel to one of the sides, then it cuts the sides of the triangle proportionally; and if the sides of the triangle are cut proportionally, then the line joining the points of section is parallel to the remaining side of the triangle". ${ }^{107}$

12.1. Trzeci rozdział Grundlagen der Geometrie Davida Hilberta nosi tytuł Teoria proporcji. Główne twierdzenie tego rozdziału to:

„Twierdzenie 42. Jeżeli dwie równoległe wyznaczaja na ramionach kąta odcinki $a, b$ oraz $a^{\prime}, b^{\prime}$, wówczas zachodzi proporcja $a: b=a^{\prime}: b^{\prime \prime} .{ }^{108}$

Spójrzmy na samą definicję proporcji:

„Jeżeli $a, b, a^{\prime}, b^{\prime}$ są czterema odcinkami, to niech proporcja $a: b=a^{\prime}: b^{\prime}$ óznacza nic innego, jak równość odcinków $a b^{\prime}=b a^{\prime \prime} .109$

Wcześniej Hilbert oczywiście zdefiniował iloczyn $a b$, mianowicie:

„Aby zdefiniować geometrycznie iloczyn odcinka $a$ przez odcinek $b$ wykorzystamy następującą konstrukcję: Wybieramy odcinek, który pozostaje ustalony w toku dyskusji i oznaczamy go przez 1. Teraz, na jednym z boków trójkąta prostokątnego odkładamy od wierzchołka $O$ [wierzchołek przy kącie prostym - P.B.] odcinki 1 i $b$. Następnie na drugim boku [drugiej przyprostokątnej - P.B.] odkładamy odcinek $a$. Końce odcinków 1 oraz $a$ łączymy linią i prowadzimy prostą równoległą do niej przechodząca przez koniec odcinka $b$. Wyznaczy ona na drugim boku odcinek $c$. Odcinek ten nazywamy iloczynem odcinka $a$ przez odcinek $b$ i oznaczamy $c=a b "{ }^{110}$

Opisana konstrukcja znana jest ze szkolnego kursu matematyki. Różnica polega jednak na tym, że w szkole jest ona uzasadniona twierdzeniem Talesa, natomiast u Hilberta konstrukcja ta prowadzi do twierdzenia Talesa, a jest oparta na twierdzeniu Pascala:

\footnotetext{
${ }^{106}$ [Euklides], V, tw. 8. Symbolicznie: $A>C \rightarrow A: B \succ C: B$ oraz $A>C \rightarrow B: C \succ B: A$.

107 [Euklides], VI, tw. 2.

108 [Hilbert 1930], s. 65.

${ }^{109}$ [Hilbert 1930], s. 64.

${ }^{110}$ [Hilbert 1930], s. 60-61.
} 
„Twierdzenie 40 (twierdzenie Pascala): Niech punkty $A, B, C$ oraz $A^{\prime}, B^{\prime}, C^{\prime}$ leżą na przecinających się liniach i będą różne od punktu przecięcia. Jeżeli $C B^{\prime}$ jest równoległa do $B C^{\prime}$ i $C A^{\prime}$ jest równoległa do $A C^{\prime}$, to jest równoległa do ". ${ }^{111}$

Dowodząc tego twierdzenia Hilbert definiuje ,symbol $\alpha c^{\prime \prime}$ gdy $c$ jest przeciwprostokątną trójkąta prostokątnego, $\alpha$ - kątem utworzonym przez $c$ i przyprostokątna $a$, to przyprostokątna $a$ jest jednoznacznie wyznaczona przez bok $c$ oraz kąt $\alpha$;

„W skrócie, $a=\alpha c$, tak że kiedy tylko $c$ jest danym odcinkiem zaś $\alpha$ danym kątem ostrym, to symbol $\alpha c$ zawsze oznacza określony odcinek". ${ }^{112}$

Hilbert zdefiniował więc nie tylko iloczyn odcinków, ale także iloczyn kąta ostrego i odcinka. Lecz co ważniejsze, jak pisze we wprowadzeniu do teorii proporcji:

„W tym i w następnym rozdziale przyjmujemy aksjomaty płaszczyzny wszystkich grup z wyjątkiem aksjomatu ciągłości, tj. Aksjomaty I, 1-3 [Aksjomaty Incydencji - P.B.], oraz II-IV [Aksjomaty Porządku, Przystawania i Aksjomat Równoległych - P.B.]. W tym rozdziale, stosując wyżej wspomniane aksjomaty chcemy ustanowić Euklidesa teorię proporcji, tj. na płaszczyźnie i niezależnie od Aksjomatu Archimedesa". ${ }^{113}$

12.2 W czwartym rozdziale, włączając do rozważań aksjomat Archimedesa, ale wciąż bez aksjomatu ciągłości, Hilbert rozwija teorię pól figur płaskich. Twierdzenie Euklidesa VI.1

„Triangles and parallelograms which are under the same height are to one another as their bases", ${ }^{114}$

odnajdujemy w definicji pola trójkąta:

„Definicja. Jeżeli w trójkącie $A B C$, o bokach $a, b, c$ są wystawione dwie wysokości $h_{a}=A D$ oraz $h_{b}=B E$, to z podobieństwa trójkątów $B C E$ i $A C D$, na podstawie twierdzenia 41 , wynika proporcja $a: h_{b}=b: h_{a}$, tj. $a h_{a}=b h_{b}$. Stąd w każdym trójkącie iloczyn podstawy przez odpowiednią wysokość nie zależy od boku, który jest wybrany jako podstawa. [...]". ${ }^{115}$

Wobec wskazanej niezależności Hilbert przyjmuje, że pole trójkąta to połowa odcinka, który jest iloczynem podstawy i odpowiedniej wysokości.

Podajmy jeszcze, $\mathrm{k}$ woli uzupełnienia, definicję podobieństwa trójkątów:

„Dwa trójkąty są podobne, gdy odpowiednie kąty są przystające", 116

i twierdzenie 41:

„Jeżeli $a, b$ i $a^{\prime}, b^{\prime}$ są odpowiednimi bokami dwóch trójkątów [podobnych - P.B.], to zachodzi proporcja $a: b=a^{\prime}: b^{\prime \prime} .117$

12.3. W Suplemencie II, zamieszczonym w dziesiątym wydaniu Grundlagen Hilbert przedstawia jeszcze jedną, ,prostszą-- jak pisze - teorię proporcji. Przyjmując, że $a, b$ są przyprostokątnymi trójkąta prostokątnego, $a: b$ to, ex definitione kąt tego trójkąta leżący naprzeciwko boku $a$. Proporcja

\footnotetext{
${ }^{111}$ [Hilbert 1930], s. 54. Twierdzenie jest opatrzone rysunkiem, gdzie na jednym ramieniu kąta leżą kolejno, licząc od wierzchołka, punkty $A^{\prime}, B^{\prime}, C^{\prime}$, a na drugim - punkty $C, B, A$.

${ }^{112}$ [Hilbert 1930], s. 54.

113 [Hilbert 1930], s. 53-54.

${ }^{114}$ [Euklides], VI, tw. 1.

115 [Hilbert 1930], s. 75.

116 [Hilbert 1930], s. 64.

${ }^{117}$ [Hilbert 1930], s. 64. Twierdzenie to odnajdujemy w Elementach w definicji podobieństwa: „Similar rectilinear figures are such as have their angles severally equal and the sides about the equal angles proportional"[Euklides], VI, def. 1.
} 
jest wówczas zdefiniowana jak następuje:

$$
a: b=c: d \leftrightarrow_{d f} \alpha=\gamma,
$$

gdzie $\alpha$ jest kątem leżącym naprzeciwko boku $a$, zaś $\gamma$ - kątem leżący naprzeciwko boku $c$ w trójkącie prostokątnym o przyprostokątnych $c$ i $b .{ }^{118}$ Odpowiednikami twierdzeń z Księgi V, kolejno V.9, V.16, V.23, są twierdzenia:

$$
\begin{gathered}
a: b=a: c \rightarrow b=c, \\
a: b=c: d \rightarrow a: c=b: d, \\
\left(a: b=b^{\prime}: a^{\prime} \wedge b: c=c^{\prime}: b^{\prime}\right) \rightarrow a: c=c^{\prime}: a^{\prime} .
\end{gathered}
$$

Są one dowodzone w oparciu o odpowiednie twierdzenia geometryczne i, inaczej niż to jest $u$ Euklidesa, bez pojęcia nierówności stosunków.

Dalej Hilbert pisze:

„Pozostaje teraz udowodnić podstawowe twierdzenie teorii proporcji. Jeżeli dwie proste równoległe na jednym boku kąta wyznaczają odcinki $a, a^{\prime}$, zaś na drugim $b, b^{\prime}$, wówczas zachodzi proporcja $a: a^{\prime}=b: b^{\prime \prime} .119$

Reasumując: Przedłożone przez Hilberta teorie proporcji mają odpowiadać twierdzeniom, jakie znajdujemy w Księdze VI. Są one oparte na aksjomatach geometrii i w tym sensie nie mają nic wspólnego z definicją proporcji i twierdzeniami Księgi V. W tym zakresie, w jakim traktują o proporcjach odcinków są one niezależne od aksjomatu ciągłości oraz Aksjomatu Archimedesa (w wersji (A)), natomiast w teorii pól figur płaskich, teoria Hilberta jest rozwijana niezależnie od aksjomatu ciagłości. W teorii ,prostszejźdefiniowany jest stosunek, a proporcja jest równością stosunków. W teorii przedstawionej w trzecim rozdziale Grundlagen, w ogóle nie jest zdefiniowany stosunek, tym niemniej w obydwu przypadkach Hilbert dowodzi twierdzenie Talesa. ${ }^{120}$

12.4. W Podstawach geometrii Karola Borsuka i Wandy Szmielew, w rozdziale Geometria Euklidesa znajdujemy trzy twierdzenia wprost nawiązujące do Elementów: twierdzenie o sumie kątów trójkąta, twierdzenie Talesa i twierdzenie Pitagorasa. Twierdzenie Talesa jest tak sformułowane:

„Dane są dwie proste $K$ i $L$ przecinające się w pewnym punkcie $p_{0}$ oraz dwie proste równoległe $M_{1}$ i $M_{2}$ nie przechodzace przez punkt $p_{0}$ i przecinające odpowiednio prostą $K \mathrm{w}$ punktach $a_{1}$ i $a_{2}$, a prosta $L$ w punktach $b_{1}$ i $b_{2}$. Wówczas

$$
\frac{\rho\left(p_{0}, a_{1}\right)}{\rho\left(p_{0}, a_{2}\right)}=\frac{\rho\left(p_{0}, b_{1}\right)}{\rho\left(p_{0}, b_{1}\right)}=\frac{\rho\left(a_{1}, b_{1}\right)}{\rho\left(a, b_{2}\right)},{ }^{121}
$$

gdzie $\rho\left(p_{0}, a_{1}\right)$ to długość odcinka $p_{0} a_{1}$.

Między tym twierdzeniem a twierdzeniem VI.2 zachodzi radykalna różnica: twierdzenie Euklidesa orzeka o proporcji odcinków, u Borsuka i Szmielew twierdzenie Talesa orzeka o ilorazach długości odcinków, czyli o ilorazach odpowiednich liczb rzeczywistych.

W wykładzie Borsuka i Szmielew liczby rzeczywiste występują już w samej definicji podobieństwa:

\footnotetext{
${ }^{118}$ Zob. [Hilbert 1980], ss. 203-206.

${ }^{119}$ [Hilbert 1980], s. 204.

${ }^{120}$ Por. „Z niego [twierdzenie VI.1 - P.B.] wywodzi się twierdzenie Talesa, które we wszystkich współczesnych wykładach gra rolę fundamentu i jest uzasadnione w oparciu o przyjmowaną w tych wykładach definicję równości stosunków"[Kulczycki 1973], s. 265.

${ }^{121}$ [Borsuk, Szmielew 1972], s. 216. Dokładniej, pod nazwą twierdzenie Talesa wystepuje takie twierdzenie: „Dowolne rzutowanie równoległe $f$ prostej $K$ na prostą $L$ jest podobieństwem"[Borsuk, Szmielew 1972], s. 216, zaś twierdzenie, które cytujemy jako twierdzenie Talesa jest podane bez nazwy jako wniosek z twierdzenia Talesa.
} 
„Przekształcenie $f$ figury $F_{1}$ na figurę $F_{2}$ nazywamy podobieństwem jeśli istnieje stała $\lambda$ taka, że $\rho(f(p), f(q))=\lambda \cdot \rho(p, q)$, dla dowolnych dwóch punktów $p, q \in F_{1}[\ldots] " .{ }^{122}$

To, co u Hilberta jest definicją podobieństwa trójkątów w Podstawach geometrii jest twierdzeniem:

„Dane są dwa trójkąty $a_{1} b_{1} c_{1}$ i $a_{2} b_{2} c_{2}$. Jeśli $\angle a_{1} \equiv \angle a_{2}, \angle b_{1} \equiv \angle b_{2}$ i $\angle c_{1} \equiv \angle c_{2}$, to trójkąt $a_{1} b_{1} c_{1}$ jest podobny do trójkąta $a_{2} b_{2} c_{2}[\ldots] " .{ }^{123}$

Teoria podobieństwa przedstawiona w Podstawach geometrii, w odróżnieniu od teorii Hilberta, obejmuje nie tylko odcinki i wielokaty, ale także kąty. Czytamy:

„Dla dowolnego podobieństwa $f$ i dla dowolnego kąta $A B$

$$
f(A) f(B) \equiv A B^{\prime \prime}{ }^{124}
$$

Jest to możliwe dzięki temu, że w wykładzie Borsuka i Szmielew twierdzenie o istnieniu miary dowodzone jest i dla odcinków, i dla kątów. W ten sposób twierdzeniu Euklidesa

„In any triangle, if one of the sides is produced, then the exterior angle equals the sum of the two interior and opposite angles, and the sum of the three interior angles of the triangle equals two right angles", ${ }^{125}$

w Podstawach geometrii odpowiada twierdzenie:

„W każdym trójkącie suma rozwartości kątów jest równa $\pi$, ${ }^{126}$

gdzie rozwartość kąta to miara kąta (a więc pewna liczba rzeczywista), a $\pi$ to liczba rzeczywista, a nie kąt półpełny.

Dowodząc twierdzenia o istnieniu miary kątów Karol Borsuk i Wanda Szmielew ustanawiają podstawy trygonometrii, gdzie porównywane są nie odcinki i kąty, ale miary kątów i miary odcinków. W konsekwencji, w euklidesowej przestrzeni wektorowej kąt nie jest już figurą geometryczną, ale, ex definitione, liczbą rzeczywistą:

„Przez kąt między wektorami $a$ i $b$ rozumiemy taką liczbę rzeczywistą $\vartheta \in[0, \pi), \dot{z e}$

$$
\cos \vartheta=\frac{|a|^{2}+|b|^{2}-|a-b|^{2}}{2|a||b|}{ }^{127}
$$

12.5. Zrazu wydaje się, że Euklidesa teoria proporcji też traktuje o kątach. Zobaczmy:

„Angles in equal circles have the same ratio as circumferences on which they stand whether they stand at centres or at the circumferences". ${ }^{128}$

Jednak w przypadku kątów jedno z założeń Księgi V, mianowicie $A \in W \rightarrow n A \in W$ staje się problematyczne, bo jak rozumieć np. $5 A$, gdy $A$ jest kątem prostym. ${ }^{129}$

\footnotetext{
${ }^{122}$ [Borsuk, Szmielew 1972], s. 164.

123 [Borsuk, Szmielew 1972], s. 217.

${ }^{124}$ [Borsuk, Szmielew 1972, s. 166.

125 [Euklides], I, tw. 32.

${ }^{126}$ [Borsuk, Szmielew 1972], s. 211.

${ }^{127}$ [Sieklucki 1978], s. 64], przy czym $|a|$, to długość wektora $a$.

${ }^{128}$ [Euklides], VI, tw. 33.

${ }^{129} \mathrm{Z}$ dowodu twierdzenia VI.33 wynika, że suma kątów środkowych ustalonego koła to kąt, który powstaje przez przyłożenie jednego kąta do drugiego, ale wtedy będzie $5 A=A$.
} 
W Podstawach geometrii kwestia ta jest jasno postawiona:

„W przeciwieństwie jednak do odcinków swobodnych dodawanie kątów swobodnych nie zawsze jest wykonalne". 130

Borsuk i Szmielew prowadzą swój wykład geometrii na gruncie wszystkich aksjomatów, a więc i aksjomatu ciągłości. Stąd odcinki swobodne spełniają Aksjomat Archimedesa (w wersji (A)). Prawdziwe jest też twierdzenie odpowiadające krokowi dowodowemu, o którym pisaliśmy w punkcie 5., mianowicie:

„Jeżeli odcinek swobodny $a$ jest mniejszy od odcinka swobodnego $b$, to istnieje taka liczba naturalna $n$, że $n a \leq b$, ale $(n+1) a>b^{\prime \prime}{ }^{131}$

Dla kątów jednak odpowiednie twierdzenie nie zachodzi. Mamy bowiem

„Jeżeli kąt swobodny $U$ jest mniejszy od kąta swobodnego $B$, to dla pewnej liczby naturalnej $n$ istnieje iloczyn $n U$ i oraz $n U \leq B$ jeśli istnieje iloczyn $(n+1) U$, to $(n+1) U>B$ ". ${ }^{132}$

Z uwagi na zastrzeżenie ,jeśli istnieje iloczyn $(n+1) U^{\prime \prime}$, aksjomat Archimedesa ani w wersji (E), ani w wersji (A) nie jest spełniony w odniesieniu do kątów. Z tego punktu widzenia zachodzi istotna między teorią podobieństwa odcinków i kątów.

12.6. Spójrzmy teraz na założenia o strukturze wielkości $\mathfrak{W}=(W,+,<)$, jakie można znaleźć w dowodach twierdzeń Księgi V. A znajdujemy takie oto:

(0) $A \in W \rightarrow n A \in W,{ }^{133}$

(1) $\forall A \forall n \exists B[n B=A],{ }^{134}$

(2) $A>C \rightarrow \exists E \in \mathfrak{M}[C+E=A],{ }^{135}$

(3) $\neg(A: B:: C: D \wedge A: B \succ C: D),{ }^{136}$

(4) $\neg(A: B \succ C: D \wedge C: D \succ A: B),{ }^{137}$

(5) $A>C \rightarrow A+B>C+B,{ }^{138}$

(6) $\forall A, B, C \in \mathfrak{M} \exists X \in \mathfrak{M}[A: B:: C: X] .{ }^{139}$

O założeniu (1) wiadomo, że przyjmując metody konstrukcji zakładane w geometrii Euklidesa, nie istnieje takie $B$, aby $3 B$ było równe kątowi trójkąta równobocznego. $\mathrm{Z}$ uwagi na to, że Eudoksosa teoria proporcji ma obejmować także kąty, równie wątpliwe jest założenie (0), bo przede wszystkim nie wiadomo jak rozumieć sumę kątów. A wreszcie nie wiadomo, czy można tak zdefiniować sumę kątów, aby dodawanie było zgodne z porządkiem, tj. wątpliwe jest założenie (5).

\footnotetext{
${ }^{130}$ [Borsuk, Szmielew 1972], s. 112.

${ }^{131}$ [Borsuk, Szmielew 1972], s. 144. Odróżnienie odcinek - odcinek swobodny, a później kąt — kąt swobodny, nie ma w tym kontekście znaczenia.

${ }^{132}$ [Borsuk, Szmielew 1972], s. 145.

${ }^{133}$ Zob. [Euklides], V, passim.

${ }^{134}$ Zob. [Euklides], V, tw. 5.

${ }^{135}$ Zob. [Euklides], V, tw. 8.

${ }^{136}$ Zob. [Euklides], V, tw. 9.

${ }^{137}$ Zob. [Euklides], V, tw. 10.

${ }^{138}$ Zob. [Euklides], V, tw. 12, 25.

${ }^{139}$ Zob. [Euklides], V, tw. 18.
} 
O ile więc pozostajemy na płaszczyźnie filologiczno-historycznej fakt, że definicja $\left(3^{\prime}\right)$ stoi w sprzeczności z twierdzeniem V.8 wcale nie musi być rozstrzygający. Pozostając zaś na płaszczyźnie matematycznej z całą pewnością możemy powiedzieć, że współczesne teorie proporcji, być może ze względu na wskazane wątpliwości, nie mają żadnego związku z definicją V.5. Pewne jest też, że teoria liczb rzeczywistych nie jest teorią proporcji w dzisiejszym rozumieniu. ${ }^{140}$ Pozostaje jeszcze kwestia ewentualnego związku teorii liczb rzeczywistych z teorią proporcji Eudoksosa, tj. z Księga V. Zwolenników tezy „o zgodności między Euklidesa definicją równości stosunków i współczesna teorią liczb niewymiernych pochodzącą od Dedekinda"możemy teraz spytać: do której wersji definicji równości stosunków odnosi się ich teza? W innym miejscu pokażemy, że teza ta jest fałszywa bez względu na to, która wersja definicji V.5 zostanie przyjęta. ${ }^{141}$

\footnotetext{
${ }^{140}$ Por. „Teoria Dedekinda jest rozszerzeniem teorii proporcjonalności Eudoksosa - Dedekind dodał np. zasadę ciągłości"[Murawski 2002], s. 49, przypis 6. Por. także „Ciekawe, że już po rozwinięciu się analizy matematycznej, pojęcie proporcji jest bardziej podobne do ujęcia arytmetycznego pitagorejczyków niż do ujęcia geometrycznego Eudoksosa. Nawet gdy stosunek nie daje się wyrazić jako iloraz dwóch liczb całkowitych, obecnie podstawiamy zań jedną liczbę i jeden symbol, jak $\pi$ czy $e^{\prime \prime}[$ Boyer 1964], s. 55. Faktem jednak jest, że ani w teorii liczb rzeczywistych, ani w analizie matematycznej w ogóle nie występuje ani pojęcie stosunku, ani pojęcie proporcji.

${ }^{141}$ Zob. [Błaszczyk 2007].
} 


\section{Dodatek}

1. Niech $\mathfrak{R}=(\mathbb{R},+, \cdot, 0,1,<)$ będzie ciałem uporządkowanym w sposób ciągły. ${ }^{142}$ Niech $F$ będzie ultrafiltrem na zbiorze $\mathbb{N}$ zawierającym filtr Frecheta

$$
\{A \subset \mathbb{N}: \mathbb{N} \backslash A \text { jest zbiorem skończonym }\} .
$$

W zbiorze $\mathbb{R}^{\mathbb{N}}$ definiujemy relację

$$
\left(a_{n}\right) \equiv\left(b_{n}\right) \leftrightarrow d f\left\{n \in \mathbb{N}: a_{n}=b_{n}\right\} \in F .
$$

Pokazuje się, że $\equiv$ jest relacją równoważności.

Niech $\mathbb{R}^{*}$ oznacza zbiór ilorazowy $\mathbb{R}^{\mathbb{N}} / \equiv$, niech $\mathbb{N}^{*}$ oznacza zbiór ilorazowy $\mathbb{N}^{\mathbb{N}} / \equiv$, niech $\mathbb{Q}^{*}$ oznacza zbiór ilorazowy $\mathbb{Q}^{\mathbb{N}} / \equiv$.

W zbiorze $\mathbb{R}^{*}$ definiujemy działania oraz porządek:

$$
\begin{gathered}
{\left[\left(a_{n}\right)\right]+_{F}\left[\left(b_{n}\right)\right]=_{d f}\left[\left(a_{n}+b_{n}\right)\right], \quad\left[\left(a_{n}\right)\right] \cdot_{F}\left[\left(b_{n}\right)\right]=_{d f}\left[\left(a_{n} \cdot b_{n}\right)\right],} \\
{\left[\left(a_{n}\right)\right]<_{F}\left[\left(b_{n}\right)\right] \leftrightarrow_{d f}\left\{n \in \mathbb{N}: a_{n}<b_{n}\right\} \in F .}
\end{gathered}
$$

Gdy $r \in \mathbb{R}$, to $r^{*}$ oznacza klasę równoważności ciągu stałego $(r, r, r, \ldots)$, tj. $r^{*}=[(r, r, r, \ldots)]$. Pokazuje się, że

$$
\mathfrak{R}^{*}=\left(\mathbb{R}^{*},+_{F}, \cdot_{F}, 0^{*}, 1^{*},<_{F}\right)
$$

jest ciałem uporządkowanym; ciało to nazywamy ciałem niestandardowych liczb rzeczywistych.

2. Wartość bezwzględną w $\mathfrak{R}^{*}$ definiujemy tak, jak w dowolnym ciele uporządkowanym:

$$
|a|=\left\{\begin{array}{cc}
a, & \text { dla } a \geq_{F} 0^{*}, \\
-a, & \text { dla } a<_{F} 0^{*} .
\end{array}\right.
$$

Zbiór

$$
O=\left\{x \in \mathbb{R}^{*}: \exists \theta \in \mathbb{R}_{+}\left[|x|<_{F} \theta^{*}\right]\right\}
$$

nazywamy zbiorem liczb ograniczonych.

Zbiór

$$
\Omega=\left\{\varepsilon \in \mathbb{R}^{*}: \forall \theta \in \mathbb{R}_{+}\left[|\varepsilon|<_{F} \theta^{*}\right]\right\}
$$

nazywamy zbiorem nieskończenie małych.

Przykłady nieskończenie małych: $\varepsilon=\left[\left(\frac{1}{n}\right)\right]=\left[\left(1, \frac{1}{2}, \frac{1}{3}, \ldots\right)\right], \varepsilon^{2}=\left[\left(\frac{1}{n^{2}}\right)\right]=\left[\left(1, \frac{1}{2^{2}}, \frac{1}{3^{2}}, \ldots\right)\right]$. Ogólnie: gdy $\left(a_{n}\right) \subset \mathbb{R}$ i $\lim _{n \rightarrow \infty} a_{n}=0$, to $\left[\left(a_{n}\right)\right] \in \Omega$. Istotnie, dla dowolnego $\theta \in \mathbb{R}_{+}$istnieje takie $n_{0}$, że dla $n>n_{0}$ jest $\left|a_{n}\right|<\theta$. Stąd wynika, że

$$
\left\{n \in \mathbb{N}:\left|a_{n}\right|<\theta\right\} \supseteq\left\{n \in \mathbb{N}: n>n_{0}\right\} \in F,
$$

i ostatecznie $\left\{n \in \mathbb{N}:\left|a_{n}\right|<\theta\right\} \in F$.

Pokazuje się, że zachodzi twierdzenie:

$$
\forall a \in O \exists ! r \in \mathbb{R}\left[a \approx r^{*}\right] .
$$

Liczbę $r^{*}$ występującą w tezie tego twierdzenia nazywa się częścią standardowa liczby $a$ i oznacza st $(a)$.

\footnotetext{
${ }^{142}$ Opracowane na podstawie: [Capiński, Cutland 1995], [Goldblatt 1998], [Lindstrøm 1988].
} 
3. Można pokazać, że $\left(\left\{r^{*}: r \in \mathbb{R}\right\},+_{F}, \cdot_{F}, 0^{*}, 1^{*},<_{F}\right)$, gdzie porządek $<_{F}$ jest odpowiednio zawężony, jest ciałem izomorficznym z ciałem liczb rzeczywistych $\Re$. Można pokazać, że $\left(\left\{q^{*}: q \in\right.\right.$ $\left.\mathbb{Q}\},+_{F}, \cdot_{F}, 0^{*}, 1^{*},<_{F}\right)$, gdzie porządek $<_{F}$ jest odpowiednio zawężony, jest ciałem izomorficznym z ciałem liczb wymiernych $\mathfrak{Q}=(\mathbb{Q},+, \cdot, 0,1,<)$. Na tej podstawie przyjmujemy, że $\mathfrak{R}$ oraz $\mathfrak{Q}$ sa podciałami ciała $\mathfrak{R}^{*}$. Zwrot ,standardowa liczba rzeczywistaóznacza wówczas element ciała $\mathfrak{R}$, a „standardowa liczba wymierna- element ciała $\mathfrak{Q}$. Przyjmując tę konwencję twierdzenie o części standardowej tak zapiszemy:

$$
\forall a \in O \exists ! r \in \mathbb{R}[a \approx r] .
$$

\section{Bibliografia}

Aaboe A. (1968), Matematyka w starożytności, tł. R. Ramer, PWN, Warszawa.

Acerbi F. (2003), Drowning by Multiples. Remarks on the Fifth Book of Euclid's Elements, with Special Emphasis on Prop. 8, Archive for History of Exact Sciences 57, ss. 175-242.

Archimedes, On the Sphere and Cylinder, [w:] [Heath 1912].

Artmann B. (1991), Euclid's Elements and its Prehistory, Apeiron, XXIV (4), ss. 1-47.

Arystoteles, Kategorie, [w:] Arystoteles, Dzieła wszystkie, t. I, tł. K. Leśniak, PWN, Warszawa 1990.

Baron M. (1969), The Origins of the Infinitesimal Calculus, Pergamon Press, Oxford.

Baszmakowa I.G. (1975), Grecja starożytna, [w:] Historia matematyki, t. 1, A.P. Juszkiewicz (red.), tł. St. Dobrzycki, PWN, Warszawa, ss. 64-115.

Baszmakowa I.G. (1975), Kraje hellenistyczne i imperium rzymskie, [w:] Historia matematyki, t. 1, A.P. Juszkiewicz (red.), PWN, tł. St. Dobrzycki, Warszawa, ss. 116-167.

Batóg T. (2000), Dwa paradygmaty matematyki, Wydawnictwo Naukowe UAM, Poznań.

Berggren J.L. (1984), History of Greek Mathematics: A Survey of Recent Research, Historia Mathematica 11, ss. 394-410. Błaszczyk P. (2007), Eudoxos versus Dedekind, Filozofia Nauki.

Borsuk K., Szmielew W. (1972), Podstawy geometrii, PWN, Warszawa.

Boyer C.B. (1964), Historia rachunku różniczkowego i całkowego i rozwój jego pojęć, tł. S. Dobrzycki, PWN, Warszawa.

Bourbaki N., (1966), Historical Note, [w:] [Bourbaki 1966(a)], ss. 406-416; cytowane za: Liczby rzeczywiste, [w:] N. Bourbaki, Elementy historii matematyki, tł. S. Dobrzycki, PWN, Warszawa 1980, ss. 186-197.

Bourbaki N. (1966(a)), General Topology, Part 1., Addison-Weseley, Reading, Massachussetts.

Capiński M., Cutland N. J. (1995), Nonstandard Methods for Stochastic Fluid Mechanics, World Scientific, Singapore 1995.

Claphan Ch., Nicholson J. (2005), The Concise Dictionary of Mathematics, Oxford University Press, Oxford.

Cohen, L.W., Ehrlich G. (1963), The Structure of the Real Number System, Van Nonstrand, Princeton, New Jersey.

Conway J. (1994), The Surreals and the Reals, [w:] [Ehrlich 1994], ss. 93-103.

Coxeter H.S.M. (1967), Wstep do geometrii dawnej i nowej, tł. R. Kransodębski, PWN, Warszawa.

Dedekind Richard (1872), Stetigkeit und irrationale Zahlen, Friedrich Viewing und Son, Braunschweig 1960; wydanie pierwsze: Braunschweig 1872.

Dedekind R. (1876), Gessamelte Werke, t. III, Friedrich Vieweg und Son, Braunschweig 1932, cytowane za: Z korespondencji z Rudolfem Lipschitzem, tł. R. Murawski, [w:] Filozofia matematyki, opr. R. Murawski, Wydawnictwo Naukowe UAM, Poznań 1994, ss. 149-154.

Edwards C.H. (1979), The Historical Development of the Calculus, Springer, New York.

Ehrlich P. (1994), Real Numbers, Generalizations of the Reals, and Theories of Continua, Kluwer, Dordrecht 1994.

Euklides, Elementy, [w:] [Heath 1956].

Fowler D.H. (1999), The Mathematics of Plato's Academy. A New Reconstruction, Clarendon Press, Oxford.

Fowler D.H. (1992), An Invitation to Read Book X of Euclid's Elements, Historia Mathematica 19, ss. 233-264.

Goldblatt R. (1998), Lectures on the Hyperreals, Springer, New York 1998.

Goldstein J.A. (2000), A Matter of Great Magnitude: The Conflict over Arithmetization in 16th-, 17th-and 18th-Century English Editions of Euclid's Elements Books I Through VI (1561-1795), Historia Mathematica 27, ss. 36-53.

Grattan-Guiness I. (1996), Numbers, Magnitudes, Ratios, and Proportions in Euclid's Elements: How Did He Handle Them, Historia Mathematica 23, ss. 355-375.

Hale B. (2000), Reals by Abstraction, Philosophia Mathematica 3, vol. 8, ss. 100-123.

Hale B. (2003), Real Numbers, Quantities, and Measurement, Philosophia Mathematica 3, vol. 10, ss. 304-323.

Heath T.L. (1912), The Works of Archimedes. Edited in Modern Notation with Introductory Chapters by T.L. Heath with a Supplement The Method of Archimedes. Recently Discovered by Heiberg, Dover (reprint), New York 1953.

Heath T.L. (1956), Euclid. The Thirteen Books of the Elements, vol. I-III, Cambridge University Press, Cambridge.

Heath T.L. (1981), A History of Greek Mathematics, t. I, From Thales to Euclid, Dover, New York.

Hilbert D. (1930), Grundlagen der Geometrie, Teubner, Leipzig 1930; wydanie pierwsze: Leipzig 1899.

Hilbert D. (1980), Foundations of Geometry, translated by L. Unger from the tenth German Edition, Open Court, La Salle, Illinois.

Joyce D.E. (1997), Euclid's Elements, http://aleph0.clarku.edu.

Kline M. (1972), Mathematical Thought from Ancient to Modern Times, Oxford University Press, New York.

Knorr W.R. (1996), The Wrong Text of Euclid: On Heiberg's Text and its Alternative, Centaurus 38, ss. 208-276.

Kordos M. (1994), Wyktady z historii matematyki, WSiP, Warszawa.

Kostin W. (1952), Podstawy geometrii, tł. J. Turkowska, PZWS, Warszawa. 
Kulczycki S. (1973), Z dziejów matematyki greckiej, PWN, Warszawa.

Lindstrøm T. (1988), An Invitation to Nonstandard Analysis, [w:] N. Cutland, Nonstandard Analysis and its Applications, Cambridge University Press, Cambridge, ss. 1-105.

Mioduszwski J. (1996), Ciagłość. Szkice z historii matematyki, WSiP, Warszawa.

Murawski R. (2002), Wspótczesna filozofia matematyki, PWN, Warszawa.

Nikolić M. (1974), The relation between Eudoxos' theory of proportions and Dedekind's theory of cuts, [w:] R.S. Cohen, J.J. Stachel, M.W. Wartofsky (eds.) For Dirk Struik, D. Reidel Publishing Company, Dordrecht , ss. 225-243.

Rosenfeld B.A. (1988), A History of Non-Euclidean Geometry, Springer, New York.

Sieklucki K. (1978), Geometria i topologia. Czesśc I. Geometria, PWN, Warszawa.

Stein H. (1990), Eudoxos and Dedekind: on the Ancient Greek Theory of Ratios and its Relation to Modern Mathematics, Synthese 84, ss. 163-211.

Struik D.J., Krótki zarys historii matematyki. Do końca XIX wieku, tł. P. Szeptycki, PWN, Warszawa 1960.

Weyl H. (1949), Philosophy of Mathematics and Natural Science, Princeton University Press, Princeton.

Widomski J. (1996), Ontologia liczby. Wybrane zagadnienie z ontologii liczby w starożytności i średniowieczu, Wydawnictwo Uniwersytetu Jagiellońskiego, Kraków 1996.

Więsław W. (1997), Matematyka i jej historia, Nowik, Opole. 